\title{
Una mariología parenética: La Virgen María en los sermones de san Juan de Ávila
}

\author{
A Parenetic Mariology. The Virgin Mary in \\ the Sermons of Saint John of Avila
}

\author{
Álvaro Román Villalón \\ Facultad de Teología San Isidoro de Sevilla. Sevilla. España \\ alvaroroman@sanisidoro.net \\ (D) https://orcid.org/0000-0003-0119-9990
}

\begin{abstract}
Resumen: La doctrina mariana de san Juan de Ávila se encuentra recogida en sus sermones en su mayor parte, lo cual imprime en su exposición un fuerte carácter parenético, es decir, exhortativo e interpelante. En consecuencia, los temas mariológicos que trata procuran la conmoción del oyente para llamarle a la conversión.
\end{abstract}

Palabras clave: San Juan de Ávila, mariología, parénesis, sermones, virtudes de María, misterios de María, ejemplaridad

\begin{abstract}
The Marian doctrine of Saint John of Avila is collected for the most part in his sermons, which gives his exposition a strong parenetic character, that is, exhortative and challenging. Consequently, his most common Mariological themes try to move the listener into conversion.
\end{abstract}

Keywords: Saint John of Avila, Mariology, paraenesis, sermons, virtues of Mary, mysteries of Mary, exemplariness

Con el presente estudio pretendemos abordar los principales temas mariológicos tratados por el maestro Ávila (1499-1569) a partir de sus sermones, queriendo poner el acento en la impronta persuasoria de su doctrina mariana por el contexto preferentemente parenético de su exposición, adaptada a los oyentes para su mejor comprensión

* Nota del editor: El presente artículo es una reelaboración de la conferencia pronunciada por el profesor Álvaro Román Villalón en las jornadas de la cátedra de Mariología de la Facultad de Teología San Isidoro de Sevilla el 20 de mayo de 2021 (Sevilla). 
e interpelación a la santidad de vida. De este último objeto emerge el constante reclamo a imitar las virtudes de María y contemplar sus misterios no solo desde la óptica de la admiración, sino también de la ejemplaridad. De este modo, como podrá observarse, los temas que seleccionamos -inmaculada concepción, maternidad divina, virginidad perpetua, cooperación a la redención, maternidad espiritual, asunción, mediación celeste- - se hallan orientados a despertar en el oyente el espíritu de conversión.

\section{EL CARÁCTER PARENÉTICO DE LA MARIOLOGÍA AVILISTA}

La presencia de María en la doctrina avilista es más que notoria, baste recordar la mención que suele hacer de ella en el exordio de sus sermones, expresando con ello una profunda piedad mariana y una sólida confianza en la mediación de la Virgen, a la que apela para la eficacia de sus palabras en la conversión de los oyentes, ${ }^{1}$ principal fin de su predicación. A este respecto, fray Luis de Granada (15051588), discípulo y biógrafo suyo, dice de él que“estaba tan encendido y transformado en este amor y deseo de salvar las ánimas, que ninguna cosa hacía ni pensaba ni trataba, sino cómo ayudar a la salvación de ellas", ${ }^{2}$ de manera que "trabajaba por subir al púlpito, no solo con actual devoción, sino también con una muy viva hambre y deseo de ganar con aquel sermón alguna ánima para Cristo; porque esto le hacía predicar con mayor ímpetu y fervor de espíritu". ${ }^{3}$

1 Cf. Domiciano Fernández, "Culto y devoción popular a María en la obra y predicación del maestro san Juan de Ávila", en Pontificia Academia Mariana INTERNATIONALIS [PAMI], De cultu mariano saeculo XVI, Acta congressus mariologici-mariani internationalis Caesaraugustae anno 1979 celebrati, vol. IV, Romae, PAMI, 1984, 297-324; Juan EsqueRDA BIFET, "Espiritualidad sacerdotal mariana en Juan de Ávila", Estudios Marianos 35 (1970) 85-114.

2 Luis de Granada, “Vida del Padre Maestro Juan de Ávila y las partes que ha de tener un predicador del Evangelio" [1588], en Luis Sala Balust, Vidas del Padre Maestro Juan de Ávila, Barcelona, Juan Flors, 1964, 33.

3 Luis de Granada, “Vida del Padre Maestro”, 34. 
El lugar que ocupa María en sus sermones ${ }^{4}$ es tal que al grupo que abarca sus fiestas se le ha llamado "Libro de la Virgen", ${ }^{5}$ sin olvidar las numerosas menciones que de ella hace durante el año litúrgico, ${ }^{6}$ especialmente en Adviento, Navidad, Cuaresma, Pentecostés, Corpus Christi y san José. ${ }^{7}$ Tales referencias denotan su gran devoción mariana, comentada por el citado biógrafo:"era grande la devoción que a esta Señora tenía. La cual se le parecía bien en la ternura y devoción de los sermones que de ella predicaba. [...] Aconsejaba siempre y predicaba con maravilloso fervor esta devoción".${ }^{8} Y$ a pesar de sus frecuentes dolencias, "cuando venía una fiesta grande, particularmente del Santísimo Sacramento, o de Nuestra Señora, de las cuales solemnidades era devotísimo, [...] se levantaba de la cama, dándole fuerzas aquel Señor que le daba la enfermedad; y predicaba de ordinario ocho sermones". ${ }^{\prime}$

Sus sermones recogen una rica variedad de temas mariológi$\cos _{,}^{10}$ prácticamente todos los de su tiempo, anticipando algunos de los que se desarrollarán en el siglo XVII, como el de la inmaculada concepción. ${ }^{11}$ Trata la predestinación de María, la maternidad divina,

4 Seguimos la edición de Luis Sala Balust - Francisco Martín Hernández (eds.), Obras completas de San Juan de Ávila, vol. III, Madrid, BAC, 2007. Los sermones serán citados conforme a la enumeración de esta edición.

5 Comprende los siguientes: Natividad de la Virgen (60-62), Presentación de Nuestra Señora (63), Purificación de Nuestra Señora (64), Anunciación de Nuestra Señora (65 [1] y 65 [2]), Visitación de la Virgen (66), Soledad de María (67), La Virgen de las Nieves (68), Asunción de María (69-72).

6 Cf. Juan Esquerda Bifet, "La espiritualidad del itinerario litúrgico en san Juan de Ávila”, Liturgia y Espiritualidad 43 (2012) 459-467; IDEM, "El año litúrgico en los sermones de san Juan de Ávila", en AA.Vv., Fovenda sacra liturgia. Miscelánea en honor del Dr. Pere Farnés, Barcelona, Centre de Pastoral Litúrgica, 2000, 427-442.

7 Cf. Juan I. Ruiz Aldaz, "La teología mariana de los sermones de san Juan de Ávila", Scripta de Maria 9 (2012) 275-3112.

8 Luis de Granada, "Vida del Padre Maestro", 96.

9 Luis de Granada, "Vida del Padre Maestro", 93.

10 Recuérdese que la mayoría de sus sermones son apógrafos, entre ellos los marianos. Cf. SALA Balust - Martín Hernánez, Obras completas, vol. III, xxviII:"subía al púlpito. Debajo, unos estudiantes, o religiosos graves y maduros, le tomaban sus palabras. Unos luego iban a leérselos al Maestro, quien los aprobaba o sugería quizás algunas enmiendas".

11 Se le ha llamado "predicador de la Inmaculada" por las numerosas veces que alude a este misterio en sus sermones. Cf. José L. Moreno Martínez, "San Juan de Ávila, predicador de la Inmaculada", en AA. Vv., La Inmaculada Concepción en España: religiosidad, historia y arte (Colección del Instituto Escurialense de 
la virginidad perpetua, la suma santidad, la ejemplaridad, la cooperación en la redención, la maternidad espiritual, la asunción, la realeza, la mediación, etc. ${ }^{12}$ La imagen de María que de ellos se desprende no es meramente conceptual, sino experiencial, al insertarla en el contexto pastoral de la instrucción y la conversión de las almas, lo cual concede una orientación práctica a su argumentación, pudiéndose decir que su mariología es "kerigmática y parenética".${ }^{13}$ En este sentido, presenta a María como ejemplo para los fieles, reclamando como prueba de autenticidad de su devoción hacia ella la imitación de sus virtudes. ${ }^{14} \mathrm{~A}$ este respecto y conforme a su espiritualidad ascética pone el acento en la "interioridad o vivencia de María", ${ }^{15}$ es decir, en su"corazón", ${ }^{16}$ metáfora que refleja su relación única, como ejemplar, con Cristo, el Espíritu Santo y la Iglesia; concepto que concretiza las actitudes internas de María, ${ }^{17}$ haciendo que el oyente se sienta

Investigaciones Históricas y Artísticas 22), Actas del Simposium, vol. II, San Lorenzo del Escorial, Estudios Superiores del Escorial, 2005, 1299-1314.

12 Para una síntesis de su mariología véase Juan EsqueRDA BIFET, "La doctrina mariológica del Maestro san Juan de Ávila", Marianum 63 (2001) 91-114; IDEM, Introducción a la doctrina de San Juan de Ávila, Madrid, BAC, 2000, 202-215; IDEM, Diccionario de San Juan de Ávila, Burgos, Monte Carmelo, 1999 [aparecen numerosas voces relativas a la Virgen]; IDEM, "Síntesis mariológica de los escritos de Juan de Ávila", Ephemerides Mariologicae 11 (1961) 169-191; Ángel P. GonZÁLeZ GutiérRez, La actuación de María en la Iglesia de Cristo según San Juan de Ávila, Tesis Doctoral, Pamplona, Universidad de Navarra, 1984.

13 Esquerda, "La doctrina mariológica", 94. En otra ocasión lo poníamos como ejemplo de una mariología parenética: Álvaro RomÁn VILLALÓN, "La mariologia spagnola dei secoli XVI e XVII", Theotokos 22 (2014) 133-134.

14 Cf. Luis MuÑoz, "Vida y virtudes del venerable Varón el Maestro Juan de Ávila, predicador apostólico, con algunos elogios y virtudes y vidas de algunos de sus más principales discípulos" [1635], en SALa BaLust, Vidas del Padre Maestro, 493: "fue predicador fervorosísimo de la devoción de Nuestra Señora; no quedó solo en referir sus grandezas y virtudes, sino en imitarlas y persuadir que las imitasen otros".

15 EsQuerDA, "La doctrina mariológica”, 94.

16 Se trata de uno de los temas más interesantes y estudiados de la mariología avilista. Cf. Esquerda, Diccionario de San Juan de Ávila, 236-238; Jesús Solano, “El Corazón de María en los escritos de san Juan de Ávila", en PAMI, De cultu mariano saeculo XVI, 383-393; Narciso GARCíA, "El Beato Ávila, apóstol del Corazón de María", Maestro Ávila 1 (1946) 13-29 y 123-146; José CALVERAS, "La devoción al Corazón de María en el «Libro de la Virgen María» del Beato Ávila", Manresa 17 (1945) 296-346, 19 (1946) 3-29 y 221-256.

17 EsquerDA, “La doctrina mariológica”, 95. 
interpelado por su vida, sus palabras, su implicación en la redención y su interés por la salvación actual de este mismo.

Esto último hace que no se entretenga en historias legendarias o hagiográficas sobre la Virgen, las cuales podían tanto embelesar como aburrir al auditorio; prefiere, por el contrario, una buena fundamentación bíblica, ${ }^{18}$ cotejándola con el pensamiento de los Santos Padres, por ejemplo, san Agustín (354-430); pensadores medievales de relieve para la mariología como san Bernardo (1090-1153) y los textos litúrgicos, tanto los propios de la Misa como del Oficio divino. $\mathrm{Al}$ amoldar todo a los oyentes, consigue un sermón técnicamente convincente y de la máxima fidelidad al mensaje evangélico, ${ }^{19}$ evitando la exégesis sin más o la retórica estética vacía. Desde la decidida pretensión apostólica de adaptar la doctrina que predicaba a sus oyentes se explica que durante el sermón mantenga un contacto continuo con ellos, recurriendo a detalles de la vida cotidiana, haciendo comparaciones, entablando diálogos, exhortando, preguntando, exponiendo infinidad de imágenes bíblicas o metáforas y describiendo con gran dramatismo ciertas escenas que mantenían en vilo a los presentes. ${ }^{20}$

18 Cf. Jesús Pulido Arriero," «Inclinar la oreja ante toda escritura de Dios». El uso de la Biblia en San Juan de Ávila: de la Lectio a la meditatio", en Francisco J. MarTínez Rojas (coord.), El presbitero secular en el s. XXI a la luz del magisterio de San Juan de Ávila, Actas del Congreso Internacional, Jaén, Obispado de Jaén, 2020, 281-299.

19 Sobre el estilo de su predicación consúltese Sala Balust - Martín Hernández, Obras completas, vol. I, 245-258; Juan J. Gallego Palomero, "La predicación en san Juan de Ávila", en Aa.Vv., El Maestro Ávila, Actas del Congreso Internacional, Madrid, Edice, 2002, 799-849; Saturnino LóPEZ SANTIDrián, Juan de Ávila predicador de Cristo, Madrid, Edicep, 2000; Rafael M. DE Hornedo, "El estilo coloquial del Beato Ávila”, Razón y Fe 868 (1970) 513-524; Álvaro HuERGA, “El ministerio de la palabra en el Beato Juan de Ávila", en AA.Vv., Conferencias pronunciadas en la Semana Avilista celebrada en Madrid, con motivo de la apertura del IV Centenario de la muerte del Beato Maestro Juan de Ávila, Madrid, 1969, 93-147. Para la oratoria de la época véase Félix Herrero SALGADO, La oratoria sagrada en los siglos XVI y XVII, Madrid, Fundación Universitaria Española, 1996, 5 volúmenes.

20 El sentido coloquial y emotivo de su oratoria ha llevado recientemente a la hermandad del Santo Entierro de Cantillana (Sevilla) a representar el descendimiento de la cruz y la entrega del Señor a su Madre con la lectura del Sermón de la Soledad de san Juan de Ávila. 
Su conocimiento de la Sagrada Escritura es amplísimo, ${ }^{21}$ citando pasajes y versículos por doquier en clave mariológica, sin acomodaciones abusivas, confiriendo con el uso de las prefiguraciones veterotestamentarias un extraordinario lirismo a la comunicación de los temas, acorde con el cariz alegórico-suasorio de los libros sapienciales a los que tanto recurre, especialmente el Cantar de los Cantares, ${ }^{22}$ leído como una gran metáfora sobre el amor de Dios y el alma en la que se complacían los místicos. En este sentido, véase cómo describe la belleza espiritual de María en ocasión de su fiesta natalicia a partir de uno de sus versículos (Cant 6,9):

Os confesamos, Señora, que sois hermosa como la luna, y mil [cientos] ${ }^{23} \mathrm{de}$ veces muy más hermosa, pues que, en comparación de vuestra benditísima ánima y de la hermosura espiritual que en ella puso el Espíritu Santo, la luna no osará parecer; y son excedidos de vos los hermosísimos espejos de Dios, que son los espíritus angelicales bienaventurados. ${ }^{24}$

El empleo del Cantar de los Cantares, oportunidad en la que evidencia la hondura de su espiritualidad contemplativa, cobra especial protagonismo en los sermones marianos, interpretando la asociación de María a Cristo en sentido esponsalicio, ${ }^{25}$ así como la interioridad de su alma y la comunión indisoluble con él, especialmente en los sermones asuncionistas, en los que proyecta los deseos del amado y de la amada al amor inextinguible que Madre e Hijo se profesan. ${ }^{26}$

No obstante, la fuente principal para la preparación de sus sermones y que determina el estilo y el contenido de su doctrina mariana es la oración. ${ }^{27}$ Él mismo aconsejaba a sus discípulos"que quitasen del estudio y lo pusiesen en la oración, que en ella se aprendía la

21 Cf. Bernardo G. Monsegú, "Los textos mariológicos de la Escritura en las obras del Maestro Juan de Ávila", Estudios Marianos 23 (1962) 327-356.

22 Cf. Monsegú, "Los textos mariológicos de la Escritura", 340-344; EsquerdA, Diccionario de san Juan de Ávila, 140-144.

23 Me he permitido corregir la fuente consultada que parece contener aquí una errata evidente, pues transcribe"cuentos".

24 Sermón 60, Obras completas, vol. III, 804.

25 Cf. Andrés Molina Prieto, "María, Madre de Dios, en san Juan de Ávila", Estudios Marianos 68 (2002) 133.

26 Cf. Esquerda, Diccionario de san Juan de Ávila, 143-144.

27 Cf. Gallego Palomero, “La predicación en san Juan de Ávila”, 803: "Es cuidada, pero no revuelve muchos libros, sí tiene un secreto: mucha oración y todavía mucho más amor al Señor y a los hombres con los que tenía que salvarse; esto 
verdadera predicación y se alcanzaba más que con el estudio". De hecho, preparaba sus sermones"de rodillas puesto en oración" $y$ "asidas ambas manos al clavo de los pies de un santo crucifijo" ${ }^{28}$ Esto explica la profundidad de sus reflexiones y el ardor de sus palabras, vivo reflejo del celo pastoral que manifestó en la predicación y por el que, precisamente, fue llamado "Predicador apostólico".$^{29}$ De ahí que sus referencias a la Virgen estén lejos de una compleja elucubración teológica, pretendiendo, más bien, tocar el corazón de los oyentes para fomentar en ellos la devoción mariana y el espíritu de conversión. ${ }^{30}$

\section{MARÍA, SANTA E INMACULADA}

Para el maestro Ávila la santidad de María es incomparable, partiendo de un texto clave, el Protoevangelio (Gén 3,15), del que deduce su animadversión hacia el Maligno y el pecado, tanto el original, como el personal. De este modo, por ejemplo, en el sermón de la Natividad de la Virgen, contemplando a la recién nacida, se admira de que la que ahora es dulce, y lo será para Dios y los hombres, sea fuertemente reacia al demonio y al pecado:

Dulcísima es esta Niña para los hombres, blandísima y sujetísima a Dios; mas contra los pecados no hay cosa tan brava, ni tan perseguidora, ni enemiga de ellos; porque el fuerte amor que a Dios tenía la hacía aborrecerlos tanto como dijo David: Los que amáis a Dios, aborreced el mal (Sal 96,10). Tenía, pues, la Virgen un magnánimo corazón, lleno de fortaleza del cielo, con que hollaba al león y al dragón (Sal 90,13), que es el demonio, con todas sus bramuras y astucias; y él y los suyos le tenían cobrado tanto temor, que de su presencia y de su nombre iban huyendo, y iban derretidos así como cera (Sal 67,3). Porque si con San Antón esta tema [sic] tenían los demonios, que oyendo su nombre echaban a huir, ¿con cuánta más razón se debe creer que al nombre de María huirían, y con más ligereza, pues ella es la mujer de la cual está escrito que había de quebrantar la cabeza al demonio

era lo que encendía su corazón y su espíritu, y luego transmitía con ímpetu y con poder sus labios".

28 Las tres citas corresponden a diversos testimonios de su proceso de beatificación, tomados de Sala Balust - Martín Hernánez, Obras completas, vol. I, 247.

29 Sala Balust - Martín Hernánez, Obras completas, vol. I, 245.

30 Esta perspectiva interpelante de la exposición de la doctrina mariana se descubre igualmente en las cartas en las que exhorta a imitar las virtudes de la Virgen. Cf. Andrés Molina Prieto, "Presencia de María en el epistolario del Santo Maestro Juan de Ávila”, Estudios Marianos 36 (1972) 281-304. 
(cf. Gén 3,15), no sólo porque escapó del pecado original, mas de todos los otros mortales y veniales, lo cual no hizo San Antón ni otro alguno? ${ }^{31}$

En otro lugar, comparándola con el profeta Jeremías y el Bautista, que"nacieron del vientre de sus madres sin pecado original y después vivieron muy santamente", ${ }^{32}$ le dice que nada tienen que ver con ella, "pues si cuando nacieron no tuvieron pecado, fueron concebidos en él; y si cuando grandes no cometieron pecado mortal, cometieron veniales, de los cuales ninguno fue libre sino sola vos". ${ }^{33}$

Como algunos autores han advertido, el maestro Ávila es pionero en la doctrina inmaculista, ${ }^{34}$ exponiéndola con claridad, tanto en su acepción negativa, relativa a la ausencia de pecado, como positiva, es decir, en cuanto a la gracia de la que está llena, fruto de la acción del Espíritu Santo que siempre la acompaña: "igran diferencia entre el corazón de los hijos de Adán, que se quedan en su propia miseria, al corazón purísimo de aquesta Señora, al cual no tocó el pecado de Ádan, y fue tan tomado de la gracia del Espíritu Santo, que más se puede llamar divino que humano!". ${ }^{35}$ Atendiendo a esta doble consideración sobre la santidad de María ${ }^{36}$ y comparándola con la del resto de los hombres, se vuelve a ella para decirle respecto al pecado:

Ninguno que en este mundo vive ha estado [sin él] sino vos, escogida particularmente por la divina bondad para que por honra suya no cayese pecado en vos, mas toda fuésedes limpia y preciosa como oro fino; y como Jacob, recibisteis la bendición espiritual sobre todos los hombres y sobre todos los ángeles (cf. Gén 32,20), más ajena de pecados que todos y más rica de gracias y virtudes que todos. ${ }^{37}$

31 Sermón 60, Obras completas, vol. III, 806; Sermón 61, Obras completas, vol. III, 816.

32 Sermón 60, Obras completas, vol. III, 803.

33 Sermón 60, Obras completas, vol. III, 803.

34 Cf. Esquerda, Diccionario de San Juan de Ávila, 509-512; Tarsicio Herrero, "La Inmaculada en el beato Juan de Ávila", Estudios Marianos 18 (1957) 371-380. La doctrina inmaculista hubo de ser expuesta con bastante asiduidad por el maestro Ávila, lo cual explica la influencia que ejerció en su discípulo más destacado, Diego Pérez deValdivia (1510-1589), que escribió el primer tratado en castellano sobre el tema. Cf. Juan Esquerda Bifet, El tratado de la Inmaculada de Diego Pérez de Valdivia, Madrid, Universidad de Comillas, 1964.

35 Sermón 69, Obras completas, vol. III, 933.

36 Cf. Esquerda, "Síntesis mariológica", 179-183.

37 Sermón 60, Obras completas, vol. III, 803. 
Este estado de gracia singular responde al amor de Dios, el mismo por el que predestinó a ser su Madre y por el que se la llevó consigo al cielo:

Por eso se llama la primera engendrada ante toda criatura (Eclo 24,5), porque en los ojos y corazón de Dios es la más doctada de gracias que todo el restante de lo criado. Y de aquel inefable fuego de amor con que la Virgen fue amada, resultó el ser criada y reservada de todo pecado y vivir tal vida que con la gracia del Señor mereció subir hoy al cielo. ${ }^{38}$

Participando del amor que origina tal gracia, es impensable que en María pudiera haber el más mínimo vestigio de pecado, ni siquiera venial:

¡Oh sagrada María, cuán lejos estaba de vos caer en pecados chicos, y, por el consiguiente, tampoco en grandes, atemorizada con el santo temor de Dios y confortada con el grande amor suyo, que así guardaba vuestra ánima, que viniendo a ella un pecado, aunque muy liviano, era abrasado y vencido de aquel grande amor, como una pequeña y liviana paja de un fortísimo fuego! [...] El pecado original, aunque sea perdonado por el santo baptismo, no deja vivir sin pecado venial al que debajo de su poder tomó. Mas como la sacratísima Virgen María por su singular privilegio fue preservada de pecado original, tuvo vida limpísima y ajena de todo pecado: cuerpo limpio, por virginidad y ánima tal, que es llamada de Dios toda hermosa y que no hay en ella mancha (cf. Cant 4,7$).{ }^{39}$

La interpretación positiva de la doctrina inmaculista le lleva a considerar que María no solo rehúye del pecado, sino que, además, se ejercita en agradar en todo lo posible a Dios con una vida virtuosa:

No solo escogió la mejor parte cuando se determinó de querer a Dios, de no cometer contra Él ni un pecado mortal; y mejor parte cuando escogió de no le ofender ni aun venialmente, aunque le dieran mil muertes; y mucho mejor cuando su amoroso y generoso corazón escogió no sólo huir de todo pecado, mas buscar en todo lo que a Dios agradase, y de lo más agradable lo que más le agradase. Fortísimo fue su amor, que le compelía a buscar en todas las cosas el mayor contentamiento y mayor gloria del Dios de su corazón. ${ }^{40}$

\footnotetext{
38 Sermón 69, Obras completas, vol. III, 932-933.

39 Sermón 71, Obras completas, vol. III, 981.

40 Sermón 71, Obras completas, vol. III, 981.
} 
Como veremos con relación a otros temas mariológicos, el amor es la virtud que mejor resplandece en María y que la hace sin igual a todas las criaturas, incluso las espirituales, siendo así verdadera maestra del amor a Dios:

En lo primero, muchos semejables tuvo, que no cometieron pecado mortal; en lo segundo, excede a todos los hombres y mujeres que vienen de Adán por el modo ordinario de la generación, mas en las riquezas de su amor con que tenía la cumbre de gracia y de las virtudes, excede a los ángeles y a todos los espíritus celestiales, aunque sean los más altos querubines y serafines, los cuales con mucha razón pueden conocer ventaja y ser discípulos de aquesta sagrada Virgen en la escuela del amor a Dios, pues es más rica y sabia en aquesta arte, que excede y puede enseñar a todos ellos. ${ }^{41}$

A propósito de esta comparación con los ángeles, recuérdese que la iconografía inmaculista los fue incorporando, embelesados en la Virgen, no como elementos decorativos, sino, por argumentos como el del maestro Ávila, para acentuar la sobreeminencia de María: "todos los ángeles confiesan que esta Virgen es más rica que ellos en la riqueza de la gracia y virtudes y más arreada de la hermosura espiritual que de esto resulta". ${ }^{42} \mathrm{Si}$ tal belleza espiritual deja pasmados a los ángeles, cuánto más a los hombres, "pues ansí es que los ángeles se admiran y no la comprehenden, ¿qué haremos nosotros, pobres? ¿O qué es lo que nuestras lenguas torpes pueden decir de sus alabanzas, cuando las muy elegantes se hallan muy insuficientes en decir de ella?". ${ }^{43}$ En este sentido, apelando a uno de los versículos del Cantar de los Cantares que solía ser interpretado en clave inmaculista, en el exordio del sermón de la Natividad de la Virgen, se pregunta asombrado:

¿Quién porná lengua en alabar [a] aquella a quien tantos grandes se pusieron a alabar, y sobre todo el grande sobre todos los grandes, Dios? Que suyas son estas palabras: Quam pulchra es, amica mea, quam pulchra es; et tota pulchra es, amica mea, et macula non est in te! ${ }^{14}$ (Cant 4,1-7). ¡Oh biena-

\footnotetext{
Sermón 71, Obras completas, vol. III, 981-982.

Sermón 71, Obras completas, vol. III, 982.

Sermón 61, Obras completas, vol. III, 816.

44 "iQué hermosa eres, amiga mía; toda hermosa eres, amiga mía, y no hay en ti mancha alguna!".
} 
venturada Niña! ¿Y qué haremos nosotros, perplejos, que tememos alabarte, siendo como somos pocos e indignos? ${ }^{45}$

Para el maestro Ávila tanto la inmaculada concepción de María, como su santidad de vida, remiten a Cristo, índice del cristocentrismo de su mariología:

Mucho, Virgen Santísima, os ensalzó el Señor, y gran motivo fue para haceros mercedes el tomaros por Madre, porque conforme a la alteza de tal dignidad había de ser la abundancia de las gracias y dones, para dignamente recibirla y usar de ella. [...] El Señor era toda la hermosura de la santidad junta, y cada uno de los santos tiene parte de la semejanza de Él, conforme a los grados de la santidad de cada uno que del Señor recibió. Mas la más semejable a Él la Virgen bendita es. ${ }^{46}$

En cuanto a la hermosura de su santidad, en alusión a Cant 6,9 ("¿quién es esta que sale como alba, hermosa como luna?"), dice que"la Virgen sagrada todo el bien y lumbre que tiene, de Jesucristo nuestro Señor, que es sol de justicia, le viene ${ }^{\prime \prime}{ }^{47}$ de manera que toda ella, tanto en lo corporal, como en lo espiritual, tendiendo constantemente a Dios, lo refleja: "ella siempre tenía su ánima convertida y atenta a Dios, el lucidísimo sol, y con grandísimo fervor y amor y elevación de entendimiento y voluntad hacía todas sus obras, chicas y grandes, corporales y espirituales".$^{48}$ No obstante, la suma santidad de María no la exime de los sufrimientos, de modo que "siendo la más santa fue la más trabajada", ${ }^{49}$ ella que"siempre fue santa, ansí en su santa concepción como por toda su vida; mas ansí como fue llena de gracia (Lc 1,28) y santidad, como el ángel dijo, así fue también en esta vida muy lastimada con trabajos". ${ }^{50}$

Para el predicador, la excelencia de la santidad de María, siendo digna de admiración, ha de despertar deseos de conversión, como cuando al iniciar un tiempo tan propicio para ello como es la Cuaresma, en el exordio del sermón del Miércoles de Ceniza, se dirige

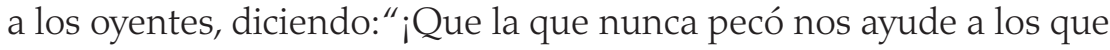

\footnotetext{
Sermón 61, Obras completas, vol. III, 817.

Sermón 75, Obras completas, vol. III, 1020.

Sermón 60, Obras completas, vol. III, 804.

Sermón 60, Obras completas, vol. III, 804.

Sermón 71, Obras completas, vol. III, 974.

Sermón 71, Obras completas, vol. III, 974.
} 
por nuestra culpa y querer caímos y a los que de nuestro poder no nos podemos levantar por más que trabajemos!" ${ }^{51}$ Igualmente, advierte en qué consiste la verdadera devoción hacia la que es"enemiga de las tinieblas". ${ }^{22}$ "seguir sus virtudes",; ${ }^{53}$ de manera que lo que más le agrada, siendo la vía para poder gozarla en el cielo, es imitarla:

¿En qué os serviremos? Si en dejar nuestros pecados os hacemos servicio, que de parte de cuantos aquí estamos digo que lo dejamos; que nos pesa de corazón de los haber hecho; que no los queremos más cometer, antes servir a Dios y a vos solamente, Señora. Aquel postrero día os veamos en vuestra silla, y os vamos a besar las manos llenas de jacintos; y estemos viendo cuán hermosa sois, [cuán] deleitable para amar, cuán alegre para consolar, cuán suave para gozar. Tan en tanto, Señora, nuestro oficio será pensar en vos, hablar de vos, seguiros a vos en vuestra vida y mirar cómo hacíades y así hacer nosotros. ${ }^{54}$

\section{UNA MATERNIDAD ASOMBROSA}

Para san Juan de Ávila la mayor de las excelencias de María es su maternidad divina: ${ }^{55}$ "¿Qué más te podemos honrar que haciéndote Virgen y Madre de Dios? Porque si santa te llamamos, muchas lo han sido, aunque no tanto; si virgen, otro que tal; si humilde, etc. ¿Qué más? En lo [que] no tienes compañía ni ternás, en lo que excedes, es en ser madre de tal Hijo, y con esto, ser virgen". ${ }^{56}$

Esta maternidad sin igual es trámite inexcusable para la fe cristológica, como cuando refiere la metáfora del ámbar que se produce por la mixtión del oro y la plata en un vaso sin la más mínima partícula de polvo. En este caso, el oro figura la divinidad, mientras la plata, la humanidad, siendo María el vaso límpido en el que ambas naturalezas se unieron al encarnarse en ella el Verbo eterno: ${ }^{57}$

Ella fue en cuyo vientre se juntó divinidad y humanidad; ella es de la cual está escripto: Vas admirabile, opus Excelsi58 (Eclo 46,12). Y de verdad admi-

\footnotetext{
Sermón 7, Obras completas, vol. III, 104; cf. Sermón 9, Obras completas, vol. III, 129.

Sermón 61, Obras completas, vol. III, 820-821.

Sermón 61, Obras completas, vol. III, 821.

Sermón 61, Obras completas, vol. III, 821.

Cf. Molina Prieto, “María, Madre de Dios”, 125-136.

Sermón 22, Obras completas, vol. III, 267.

Sermón 22, Obras completas, vol. III, 265-267.

"Vaso admirable, obra del Todopoderoso".
} 
rable, pues que en él cupo el que en el cielo y tierra no cabe. Caelum et terram ego impleo ${ }^{59}$ (Jer 23,24), y cupo en el vientre de la limpísimaVirgen. ¡Oh vientre santo, vientre puro, vientre no amancillado, no tocado! ¡ $\mathrm{Ni}$ [hay] en ti polvo de vanagloria, ni tierra de deseos de cosas de este mundo, ni humor de deseos de carne, ni viento de soberbia; vaso hecho por mano de Dios, en el cual se remiró más Dios que en todas las cosas hizo! ${ }^{60}$

Nótese cómo subraya la complacencia de Dios en María, hasta el punto de imaginárselo embelesado en esta, dando a entender, además, que la maternidad divina es el más grande de los privilegios marianos:

Y ansí, otro lugar no hubo, ni entre los ángeles ni serafines del cielo, ni [en] toda la tierra, adonde mejor ni tan bien Dios se aposentase como en el vientre de la Virgen. ¿Quién dirá las grandezas de vuestro limpio vientre, Señora, que enmudecen de hablar de él los muy sabios? Allá, Salomón, viendo en espíritu de profecía esta gran maravilla, dijo: Quis scrutabitur secreta ventris? ${ }^{61}$ (Prov 20,27). ¿Quién alcanzará a lo decir? Sólo aquel, por cierto, que os hizo y anduvo en vuestras entrañas. ${ }^{62}$

La maternidad divina le lleva a manifestar en varios de sus sermones el más profundo asombro, como el que Moisés experimentó ante la zarza ardiente que no se consumía por las llamas, misterio que para el predicador reclama la conversión:

Maravillosa es la visión del profeta, pero más maravilloso es el cumplimiento de ella. ¿Qué es fuego en zarza y no se quemar, sino Dios en el vientre de una doncella, para librarlos del pecado, y estándose entera? Si algún día tienen los predicadores necesidad de limpieza para hablar, éste es. Si algún sucio llegare a hablar de este santo misterio, dirále el Niño desde el vientre de la Madre bendicta: Si quieres llegar acá, descálzate los zapatos, porque este lugar en que estás tierra santa es. Los zapatos hácense de pellejos de animales muertos. Si quieres llegar acá a hablar de este santo misterio, quita las aficiones, que son los pies del alma, de las cosas mortales de la tierra.Y porque, para hablar de él, tenemos necesidad de limpieza y de gracia,

\footnotetext{
59 "Yo lleno los cielos y la tierra".

Sermón 22, Obras completas, vol. III, 266.

¿1 “Quién puede penetrar los escondrijos de las entrañas?".

62 Sermón 22, Obras completas, vol. III, 266.
} 
[pidámossela] $^{63}$ al mismo Señor, y pongamos a la Virgen por intercesora, diciendo: Ave, Maria. ${ }^{64}$

En el sermón de Navidad, maravillándose del misterio de esta maternidad única, confiesa: "cuando yo veo a una imagen con un Niño en los brazos, pienso que he visto todas las cosas". ${ }^{65}$ Pasmo que no excusa la curiosa comparación con una alhaja que las mujeres solían llevar, el agnusdéi, claro ejemplo de cómo se servía de elementos cotidianos para llamar la atención de los oyentes. De este modo, preguntando a laVirgen por qué pone al Niño en el pesebre, les dice:

¿Habéis visto a unas doncellas que se ponen un agnus Dei en los pechos para que las hermosee? Vuestro agnus Dei no tiene más del nombre; no tiene más de oro o plata. Mas el Agnus Dei que tiene la Virgen en sus brazos no hay cosa más hermosa, que es el sacratísimo Niño. En los brazos de su Madre más resplandece y más hermosea a su Madre que el cielo ni la tierra ni que las estrellas. ¡Bienaventurados ojos que os merecieron ver! Una cosa muy linda: la Virgen y el Niño con ella a su cuello (cf. Ap 12,1); una Luna vestida con un Sol. ${ }^{66}$

El predicador hace partícipe a la Virgen de este mismo asombro, imaginándosela arrobada en la contemplación de aquel que, paradójicamente, siendo su Creador, nace de ella:

Pues vos veis cuán hermosa estáis con Él, ¿por qué quitáis el Agnus Dei de vuestro cuello? ¿Por qué quitáis de los brazos a aquel cuyo Padre verdaderamente está en los cielos? Y cuando la Virgen vía en sus brazos aquel Señor de cielo y tierra, igual al Padre y al Espíritu Santo, de agradecimiento muchas veces creo que lloraría, y las lágrimas corrieron por su cara, y vernían a la cara del Niño y se la lavarían. " ¿Que tengo en mis brazos al que me crió!". Sabíalo agradecer. Amaba a su Hijo más que a sus ojos. ${ }^{67}$

Finalmente, ofrece la respuesta a tan inesperado desprendimiento:"quítolo", dice la Virgen, "para dároslo a vosotros. Yo lo mantendré

\footnotetext{
63 Nos permitimos corregir la versión de la fuente consultada en la que aparece "pidámosela".

64 Sermón 65 [2], Obras completas, vol. III, 878.

65 Sermón 4, Obras completas, vol. III, 77.

66 Sermón 4, Obras completas, vol. III, 77.

67 Sermón 4, Obras completas, vol. III, 77.
} 
para vuestro provecho" ${ }^{68}$ Tal generosidad despierta en el devoto sentimientos de agradecimiento y de conversión, objeto, recuérdese, del género parenético del discurso:

¿Qué te debemos Santa de las santas, Amorosa de las amorosas? ¡Que te dé Dios a su Hijo en tus entrañas, y tomas el Niño y lo mantienes para nosotros! Pensando estaba la Virgen cuando lo envolvía y lo tenía en sus brazos: “Este Cordero estoy manteniendo para los hombres; yo trabajaré, tejeré y hilaré de mis manos para mantenerlo para los hombres". $¡$ Y que no te agradezca yo que me diste un Cordero mantenido treinta tres años, Cordero gordo sin mancha! ${ }^{169}$

De semejantes palabras se deduce el carácter soteriológico de la maternidad de María, en tanto que engendra y cuida de aquel por cuyo sacrificio, en metáfora de Cordero, redime al mundo del pecado. De ahí que termine apelando a la contrición:

Mas si nos arrepentimos, podemos llegar a este Cordero, pues está en el pesebre, que es el lugar donde comen los animales. ¡Enhorabuena venga tal día, en el cual el Padre eterno nos da a su Hijo, y su santa Madre también, y el Niño lo ha por bien! ¿Qué resta sino que, echando yo de mí los pecados, reciba yo aqueste Niño y lo ose llamar de aquí adelante con gran regocijo: Niño mío y Dios mío? ${ }^{70}$

Igualmente, en el sermón en el que se sirve de la metáfora del ámbar para explicar la encarnación delVerbo, se infiere el fin salvífico de esta y la consecuente interpelación a la conversión:

¡Oh bienaventurada tú y el vientre tuyo, que tal bien nos trujo, y en cual se fabricó el ámbar excelente, Cristo, que refregado en la cruz de su pasión, atrajo y cada día atrae a nosotros pecadores, que somos pajas: Si exaltatus fuero a terra, omnia traham ad me ipsum ${ }^{71}$ (Jn 12,32). Y con mucha razón. ¿Cúyo corazón, aunque de piedra sea, no se encenderá en servir y amar a Cristo, Dios nuestro, viendo lo que por nosotros pasó?Y, por tanto, Señora, pues tanto bien por vos nos vino, nosotros nos conocemos obligados a os servir y honrar toda nuestra vida. ${ }^{72}$

Sermón 4, Obras completas, vol. III, 77.

Sermón 4, Obras completas, vol. III, 78.

Sermón 4, Obras completas, vol. III, 78.

"Una vez que yo haya sido elevado sobre la tierra, atraeré a todos hacia mí".

Sermón 22, Obras completas, vol. III, 267. 
La maternidad de María, no reducida a la generación biológica y entendida, además, soteriológicamente, tampoco se desvincula de las virtudes, especialmente la caridad, condición indispensable para la encarnación del Verbo, de manera que, en el segundo sermón de la Anunciación, dice:"la Virgen grandísima caridad tuvo. No la tomara Dios por Madre si no tuviera mucha caridad". ${ }^{73}$ Asimismo, contrasta la grandeza por ser Madre de Dios con la humildad que, por ejemplo, demuestra en visitar a su prima Isabel:

Señora, ¿no os acordáis a quién lleváis en vuestro vientre encerrado, que es tal que, por ser vos su Madre, sois la más alta criatura de la tierra y del cielo; y es razón que vos a nadie, pero todos a vos os sirvan? Ya si fuera antes de haber concebido tal Hijo, que os da a vos nombre sobre todo nombre que a criatura pura se debe, que es ser llamada Madre de Dios, no fuera tanta la humildad con que os abajáis, porque no fuera tanta la alteza que teníades; mas siendo tan alta y ensalzá[n]doos Dios con título de tanta grandeza, haceros vos pequeña con la humildad, es cosa, después de la humildad de vuestro Hijo, la más alta de todas. ${ }^{74}$

En varios de sus sermones da a entender que la maternidad divina es clave indispensable para sostener el dogma cristológico. En el de La Virgen de las Nieves, por ejemplo, recuerda la doctrina de los primeros concilios, confesando la única persona delVerbo encarnado en dos naturalezas distintas, rechazando la doctrina gnóstica o docetista de una encarnación aparente y proponiendo la veracidad de la maternidad de María como índice de la recta fe. De este modo, viendo en aquella mujer que bendijo el vientre y los pechos que criaron a Jesús (Lc 11,27) una personificación de la Iglesia, dice:

Con determinado corazón confiesa ser bienaventurada la sacratísima Virgen María y haber concebido y dado leche al verdadero Hijo de Dios; y si lo trajo en su vientre y le dio leche, verdadera madre suya es y verdadero hombre es Él; cortando la cabeza a los herejes que decían que tenía un cuerpo fantástico y no natural. Madre es la Virgen de Dios verdadero y de hombre verdadero, y aunque no madre de Dios en cuanto Dios, sino madre de Dios en cuanto hombre; mas Dios y hombre dos naturalezas, mas una persona. Es Dios e hijo de la Virgen María; mas no es dos hijos, sino uno, y por eso ella es madre del que es Dios y hombre. ${ }^{75}$

Sermón 65 [2], Obras completas, vol. III, 881.

Sermón 66, Obras completas, vol. III, 888.

Sermón 68, Obras completas, vol. III, 917. 
Todo lo cual, una vez más, es motivo para el estupor ante el misterio, así como para reconocer que la grandeza de María radica en esta maternidad singular:

¿Quién contará qué dignidad es aquesta? ¿Quién declarará la sentencia que esta mujer dijo: El vientre que te trujo y los pechos que mamaste? ¡Dignidad sobre todas las dignidades, nombre sobre todo nombre, que ni en cielo ni en tierra a pura criatura puede convenir! ¿Queréis honrar a la Virgen? Llamadla Madre de Dios humanado; porque quien esto la dice, honra le da sobre toda honra y no será sin galardón, porque ella es muy agradecida, y ama a quien la ama y honra a quien le honra. ${ }^{76}$

Pero, a tenor de la respuesta de Jesús, advierte sobre el motivo principal de la mayor bienaventuranza de su Madre, relativa a la fe, poniendo en sus labios el siguiente discurso que dirige a la mujer que la bendijo:

Tú hablas al modo común, que viendo a un hijo muy bueno, suelen llamar a su madre bienaventurada, y porque lo engendró y dio su leche. Mas esa alabanza en los ojos de Dios, cosa es de muy poco valor, y si mi Madre no tuviera virtudes, con las cuales me concibiera en su ánima y oyera y guardara la palabra de Dios, ninguna cosa le aprovechara ser madre mía sigún la carne, si no lo fuera según el espíritu. ${ }^{77}$

En la línea parenética de interpelar al oyente, pasa a subrayar que lo importante no es el parentesco carnal, sino el espiritual con Cristo, vínculo que se traduce en la obediencia de la fe:

Toda criatura se desengañe, que, pues parentesco tan cercano como es ser madre y tener hijo tan alto, como es Dios humanado, no basta para hacer a una mujer bienaventurada, menos bastarán otros linajes ni otras cosas, si no viniere parentesco espiritual con Cristo, que consiste en fe verdadera y obediencia a los mandamientos de Dios y de su Iglesia. ${ }^{78}$

En este sentido, para el maestro Ávila, María es doblemente grande, por su maternidad única y por su fe inmensa, de manera que esta maternidad no es solo en sentido biológico, sino también moral,

\footnotetext{
76 Sermón 68, Obras completas, vol. III, 917.

77 Sermón 68, Obras completas, vol. III, 917.

78 Sermón 68, Obras completas, vol. III, 918.
} 
puesto que depende de la fe, lo cual se deduce de que conciba tanto en el cuerpo, como en el alma:

¿Qué tanto bien está encerrado en oír la palabra de Dios y guardalla, que, si uno hiciese esto, sería más bienaventurado que fue la Madre de Dios, si no tuviera más que ser madre de Dios? Mas ninguno lo es, ni fue, ni será tanto como ella, porque ninguno fue madre de Él ni será. ¡Oh Madre verdaderamente bienaventurada, que con ánima y cuerpo engendraste a Jesucristo, Dios humanado! ${ }^{79}$

No quisiera terminar este apartado sin hacer mención de la relación de María con la eucaristía, tema destacado en la doctrina avilista. ${ }^{80}$ Entendiendo la eucaristía como una prolongación de la encarnación delVerbo, refuerza la fe en la presencia real de Cristo, como puede apreciarse en uno de los sermones de la Infraoctava del Corpus al establecer una analogía entre la presencia de Cristo en el vientre de María y la sacramental del mismo bajo los accidentes del pan, haciendo, de paso, que los oyentes se interroguen:

Ansí como estuvo antes ascondido en las entrañas de la Virgen, así lo está agora en los accidentes. Toma, pues, esta contemplación y ve comparando la encarnación con el Sacramento y di: "Señor, allá os abajastes al vientre, en el cual estuvisteis ascondido; acá, Señor, os abajáis a estar debajo de esos accidentes ¿Dónde estáis que no os vemos, aunque sabemos y creemos que estáis ahí?". ${ }^{81}$

Subraya tanto la identidad entre el que asumió nuestra carne del seno virginal de María y el que ahora se ofrece como alimento en la eucaristía que interpreta el misterio de la encarnación mediante imágenes relativas al sacramento, tales como el trigo y el pan, poniendo con gran belleza literaria en labios de Jesús lo que sigue:

Yo fui grano de trigo sembrado en el vientre virginal de mi sacratísima Madre (cf. Jn 12,24); salí de él tierno y fresco, como un trigo que está en berza; creciéronme aires y muy recios soles de trabajos, caminos y persecuciones; y cuando fui casi de treinta años, echaron los malos su hoz en mí, y fui cortado de esta vida, molido y atormentado, y hecho harina para que de ella

Sermón 68, Obras completas, vol. III, 918.

Cf. Esquerda, “La doctrina mariológica”, 98-99.

Sermón 41, Obras completas, vol. III, 551. 
se hiciese este pan sagrado, del cual y por el cual digo: El que me come a mí, vivirá por mí (Jn 6,58). ${ }^{82}$

El proceso de elaboración del pan proyectado en el misterio de la encarnación lo lleva a decir que"en el vientre de la Virgen fue amasado este pan, que así se llama, el pan de la Virgen". ${ }^{83}$ Siendo, pues, su pan, carne de su carne, ella es la que lo ofrece en la eucaristía:"el pan que hemos de buscar es el que la Virgen María parió en Betlem. Ella nos está rogando con Él, diciendo: Comedite panem meum et bibite vinum $^{84}$ (Prov 9,5)"; 85 poniendo en sus labios la siguiente invitación: "venid y [comed] ${ }^{86}$ del pan que yo concebí en mis entrañas y del pan que yo parí; [...] venid, que yo os tengo a Dios humanado; ya os lo traigo hecho hombre blando. Venid, que no lo quiero para mí sola, sino para todos" ${ }^{\prime 87}$

En el sermón de Navidad, el asombro que invade el corazón del predicador por el recién nacido es el mismo que experimenta ante el misterio de su presencia real en la eucaristía: "ique me ponga yo en el altar y con las palabras de la consagración que aquel mismo Señor que la Virgen parió venga a mis manos y lo meta en mi ánima!" ${ }^{88}$ En este sentido, la relación de María con la eucaristía le lleva a dirigirse a los sacerdotes para animarles a imitar su santidad a la hora de tratar el sacramento:" ¡cuán grande ha de ser nuestra santidad y pureza para tratar a Jesucristo, que quiere ser tratado de brazos y corazones limpios, y por eso se puso en los brazos de la Virgen!". ${ }^{89}$

En la peroración del segundo sermón de la Anunciación, aludiendo al mismo tema, pone de manifiesto la talentosa adaptación de su oratoria para llamar la atención de los oyentes al servirse de un dicho popular de la época — "bendito el árbol que tal fructo dio" - con el propósito de invitarles a la siguiente alabanza: "cuando viéredes a Jesucristo en la hostia consagrada, cuando comulgáredes, cuando recibiéredes a nuestro Señor, dad gracias al Padre Eterno, que os lo

\footnotetext{
Sermón 56, Obras completas, vol. III, 764.

Sermón 39, Obras completas, vol. III, 524.

"Comed mi pan y bebed mi vino".

Sermón 12, Obras completas, vol. III, 165.

Corregimos lo que parece una errata de la transcripción consultada al aparecer "comé".

87 Sermón 12, Obras completas, vol. III, 165.

88 Sermón 4, Obras completas, vol. III, 72.

89 Sermón 4, Obras completas, vol. III, 72.
} 
dio; decid: «iBendicto sea el árbol que tal fructa dio, que es la Virgen bendictísima!»"..$^{90}$

\section{EL GOZO DE LA VIRGINIDAD}

La virginidad de María también es causa de asombro, en tanto que esta, conciliada con la maternidad, revela la divinidad del engendrado, recurriendo para ello a la fe de los primeros concilios, como la fórmula del símbolo niceno-constantinopolitano concerniente a la encarnación delVerbo:" por amor de nosotros descendió de los cielos y encarnó por Espíritu Santo de Santa María Virgen. El negocio de juntarse Dios con el hombre es negocio del Espíritu Santo, no intervino obra de varón" ${ }^{91}$ A este respecto, recuérdese la interpretación de la zarza del Éxodo como prefiguración de la maternidad virginal de María, unión de contrarios tan misteriosa como el hecho de que el arbusto no se consumiera por las llamas: ¿Qué zarza es ésta, que arde y no se quema? Que vean vuestros ojos una doncella preñada: está Dios en ella y no se quema, preñada está y doncella". ${ }^{22}$ Emplea otras prefiguraciones para significar la paradoja prodigiosa de la maternidad virginal, como hace en el sermón de la Natividad de la Virgen cuando, en razón de Cant 6,9 ("¿Quién es esta, que nace como el alba?"), la presenta cual "mensajera y madre del sol", sirviéndose de las imágenes de la zarza ardiente y de la piedra desprendida del monte sin intervención humana de la profecía de Daniel, para señalar que la procedencia de Cristo solo se entiende en relación al Espíritu Santo y María:

Sin nubes nació el sol de vos, cuando concebistes y paristes a Cristo Redemptor nuestro sin pecado y sin dolor, que fue sol; empero, no os quemó, según estaba figurado en la zarza que Moisén vio (cf. Éx 3,2) y según estaba figurado por Daniel, que vio una piedra cortada de monte sin manos (Dan 2,34). Que aunque Cristo, Dios nuestro, de vuestro vientre saliese hecho hombre, el cual es dicho piedra en la Escriptura, empero en hacerse hombre no hubo mano de hombre, sino todo fue del Espíritu Santo y vuestro. ${ }^{93}$

\footnotetext{
Sermón 65 [2], Obras completas, vol. III, 885.

Sermón 39, Obras completas, vol. III, 524.

Sermón 65 [1], Obras completas, vol. III, 869.

Sermón 61, Obras completas, vol. III, 818-819.
} 
Igualmente, se figura al Espíritu Santo como el rocío que fecunda a laVirgen, haciendo que en ella"el fruto" de la maternidad no deshaga "la flor" de la virginidad:

Parecéis, Señora, más a la alba, porque así como al alba cae el rocío en los campos, y se para húmida la tierra, y se tiempla el calor, y se conservan las hierbas en su frescor, ansí en vos, Señora, llovió y cayó aquel bienaventurado rocío, el cual con gracia humedece nuestras sequedades, hace fructificar nuestras ánimas. Y esto, no quitándoos a vos la verdura de la virginidad, que, aunque fue vuestro fructo, no os quitó la flor. Que en vos sola el fructo es flor, y la flor, fructo (cf. Eclo 24,23), sicut scriptum est: Flores mei fructus, et: Ego flos campi ${ }^{94}$ (Cant 2,1). Luego flor y fructo es en vos uno. ${ }^{95}$

Para Ávila la virginidad de María es perpetua, siendo aun más maravillosa por lo que respecta al parto indoloro, al que alude frecuentemente. El hecho sorprendente de dar a luz sin dolor manifiesta la gracia singular de la que participa María, dado que fue liberada de la "maldición" consecuente del pecado original (Gén 3,16): "la Virgen libre fue de esta maldición; ansí como fue libre de todo pecado, fue libre de este dolor" ${ }^{96}$ A diferencia de las demás mujeres, su parto se caracteriza por la alegría, incluso en los momentos previos: "de manera que no hemos de imaginar a Nuestra Señora como a las otras preñadas cuando están cercanas al parto, que andan pesadas y con dolores, mas antes mientras más cercana al parto, más alegre estaba" ${ }^{97}$ Se trata, pues, de un indicio más de la divinidad del engendrado que es capaz de cambiar el curso natural de los acontecimientos. María, inundada por la alegría con la que da a luz, es la primera en adorar al recién nacido como Dios verdadero:

Siente la Virgen que ya se llega la hora del parir. La media noche, no en dolores, que no los tuvo, sino en grandísimos regocijos; y crecían más mientras más se llegaba la hora del parto. Y porque en el mesoncillo no había donde parir, vase cerca del pesebre a parir al Señor de los cielos y tierra; y arrímase a un poste del pesebre. Alza los ojos al cielo. Cuando no se cata, ve delante de sí al Niño bendito llorando. ¡Quién viera a la Virgen arrodillada delante de él!Y como sabía que era Dios, no lo osaba tomar de reve-

\footnotetext{
94 "Como está escrito: las flores son mis frutos, y yo soy la flor del campo".

95 Sermón 61, Obras completas, vol. III, 819.

96 Sermón 3, Obras completas, vol. III, 48.

97 Sermón 3, Obras completas, vol. III, 48.
} 
rencia; y, por otra parte, como era su hijo, con amor queríalo tomar. Toma licencia, y adorándolo por verdadero Dios, tomolo en su brazos. ${ }^{98}$

El parto virginal, causa de inmensa alegría para María y el mundo, refleja la paradoja sobrecogedora del misterio que se prolonga en el hecho de que una doncella, o sea, una virgen, ejerza como madre tomando al recién nacido entre los brazos. El predicador hace una encantadora composición de lugar, citando varias prefiguraciones (Is 53,1-2 y Gén 18,10-15) que apuntan al gozo de la maternidad virginal, expresión de auténtica belleza salvífica y objeto de profunda contemplación:

¡Oh Sacratísima Virgen, quién viera vuestro regocijo y el alegría de vuestra cara! ¡Quién os viera hoy madre y virgen, tan virgen como las vírgenes y tan madre como las madres! La hermosura del Carmelo y de Sarón - que eran unos montes muy hermosos en Judea- le fue dada. Y si queréis ver alguna hermosura en la tierra, suplicad a nuestro Señor que os dé ojos de consideración, para ver una doncella hoy en el portal de Betlem con un doncel en sus brazos. No hay cosa más hermosa; la honra del Líbano le fue dada, y la hermosura de Carmelo y de Sarón. ${ }^{99}$

Esto respecto a la profecía de Isaías, para continuar con la alegría de Sara que, en razón de la etimología del nombre del niño concebido milagrosamente, constituye una prefiguración del regocijo de María por el fruto de su maternidad virginal, de cuyo gozo el predicador invita a los oyentes a hacerse partícipes:

Risa me ha hecho el Señor, y no solamente para mí, pero para cuantos lo oyeren. ¡Qué palabras para la Virgen! Mucho fue que una de noventa años concibiese; pero mayor milagro, doblado, fue el de la Virgen concebir sin obra de varón y parir virgen. ¿Y quién puede oír que la Sacratísima Virgen tiene en sus brazos a Jesucristo, que no se regocije? Fue hecho gozo no solamente para la Virgen, sino para todos los que lo oyeren. Gozaos con ella todos los que bien la queréis, que hoy es hecha Madre yVirgen. ${ }^{100}$

Otro aspecto en el que insiste es el voto de virginidad de María, especialmente en los sermones de la Anunciación y de San José, de modo que esta condición no es circunstancial, sino expresión de una

98 Sermón 4, Obras completas, vol. III, 73.

99 Sermón 4, Obras completas, vol. III, 66.

100 Sermón 4, Obras completas, vol. III, 66-67. 
opción de vida decidida por María y su esposo desde antes incluso de la anunciación. De este modo, figurándose el tormento de san José al verla encinta, el predicador le dice: ${ }^{\prime}\lceil Y$ cómo Dios te ha lastimado en las mesmas niñas de tus ojos, pues ves preñada a tu esposa, y nunca has llegado a ella, ni pensaste llegar; porque ella y tú entrambos tenéis hecho voto, de común consentimiento, de guardar virginidad por toda la vida!". ${ }^{101}$ El santo, en su tribulación, deja entrever que la virginidad de María no es solo en sentido físico, sino también moral, pues sabía"que toda ella y todas sus costumbres eran más contrarias a deshonestidad que lo negro con lo blanco, y eran tan predicadoras de la limpieza virginal que en su corazón y cuerpo tenían, que daban de sí un olor como bálsamo y eran como resplandor de aquella pureza más que angelical que en su persona tenía" ${ }^{102}$

El voto de virginidad explica la pregunta de María al ángel en la anunciación, no como signo de incredulidad, sino, más bien, como expresión del firme convencimiento de permanecer virgen, incluso cuando es llamada a ser madre, nada más y nada menos, que de Dios:

Mirá que tanto es el amor que tiene la Virgen a su limpieza, que no trueca su virginidad por ser madre del Hijo de Dios. No dice si será o no, que no lo duda, mas dice:"Enseñadme cómo será; que yo he propuesto y he determinado de no conocer varón”. [...] ¡Oh bienaventurada doncella, que no osa trocar su virginidad por ser madre del Hijo de Dios! ${ }^{103}$

El predicador no pierde oportunidad para mover los afectos de los oyentes, de modo que, aprovechando la firme determinación de la Virgen en su voto, exhorta a perseverar en la castidad:" «Señora, ¿no trocaréis vuestra virginidad, sin pecado y con gran merecimiento, por ser Madre de Dios?». «No tengo propósito de conocer varón. ¡Triste de la doncella que, por una saya que le dan, pierde su virginidad!»" ${ }^{104}$

\section{SOCIA GENEROSA DEL REDENTOR}

Como se ha dicho, para el maestro Ávila la relación de María con Cristo no se limita a la generación materna, sino que es una asociación

\footnotetext{
101 Sermón 75, Obras completas, vol. III, 1003-1004.

102 Sermón 75, Obras completas, vol. III, 1004.

103 Sermón 65 [1], Obras completas, vol. III, 867.

104 Sermón 65 [1], Obras completas, vol. III, 885.
} 
absoluta y perenne a la persona y a la obra redentora del Hijo. ${ }^{105}$ Dicha asociación pertenece al diseño salvífico de Dios desde la eternidad, como se desprende del Protoevangelio $(G e ́ n$ 3,15) a propósito de la fiesta de la Natividad de la Virgen, animando al oyente a no perder la esperanza de una conversión auténtica y obtener así el perdón de Dios. El nacimiento de María constituye el anuncio profético de la redención obrada por Cristo al que esta se asocia generosamente para beneficio de todas las almas, no solo en cuanto a su consecución objetiva, sino también subjetiva, de manera que dicha cooperación, en el presente, se expresa a modo de intercesión. El predicador anima a encomendarse a ella, apelando al poder de laVirgen en razón de su maternidad divina.

No tengas, hermano, tú esas congojas; que una Niña te es nacida que ha quebrantado la cabeza del demonio, y no sólo en sí mesma, mas en las ánimas de los pecadores. Nacida te es hoy para tu consuelo y remedio; ponla por intercesora entre Dios y ti; gime tus culpas y pecados y vete a ella, que como verdadera Madre de Dios te halagará, remediará y consolará. ${ }^{106}$

La imagen que más utiliza para expresar esta asociación es la del paralelismo antitético Eva-María, planteado, al hilo del pensamiento

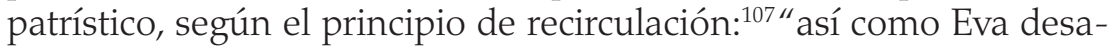
yudó al primero Adán en lo que tocaba al servicio de Dios, así esta Niña es criada para que ayude al segundo Adán, que es Jesucristo, para ayudarle a la redempción y a recoger las ánimas por [quienes] ${ }^{108}$ Él derramó su sangre" ${ }^{109}$ Planteando el mismo argumento en otra ocasión, compara a la Virgen con los sacerdotes y predicadores, colaboradores de Cristo, para concluir preguntándose:" ¿cuánto más lo será la Virgen, dando carne para la redempción y oraciones eficacísimas para que se efectúe en nosotros lo ganado en la redención?". ${ }^{110}$ Obsérvese aquí la distinción de la colaboración de María a la obra

105 Cf. Andrés Molina Prieto, “Colaboración de María a la obra redentora de Cristo en el pensamiento de San Juan de Ávila", Estudios Marianos 70 (2004) 221-234.

106 Sermón 60, Obras completas, vol. III, 813.

107 Según Esquerda, el principio mariológico"que recalca más es el de la unión (total) de María con Cristo en calidad de Madre-Esposa": (Esquerda, "Síntesis mariológica", 171).

108 Corregimos la fuente consultada en la que aparece "quien".

109 Sermón 60, Obras completas, vol. III, 812.

110 Sermón 68, Obras completas, vol. III, 924. 
redentora de Cristo conforme al lenguaje preconciliar: objetiva, en razón de la maternidad divina, y subjetiva, es decir, la intercesión celeste.

Fiel a la intención parenética de su discurso, compara la soberbia de Eva con la humildad de María con el fin de invitar a todos a imitar la virtud de esta última que es en la que se fija Dios. Para llamar la atención, emprende un monólogo en el que el oyente pregunta al predicador y este a su vez le responde:

-Padre, ¿por qué crió Dios a esta madre nuestra chiquita, la que había de remediar los males de la madre primera? ¿Por qué chiquita, la que había de levantar a los hombres de tan gran caída, como dieron por el pecado de la madre grande primera?

-Yo [o]s lo diré: Por encomendarnos la humildad del alma. Ama Dios mucho la humildad del alma, y ansí amó a la Virgen sacra por tan humilde como fue. ¿Veisla chiquita? Pues más lo fue en su propia estimación. Miró el Señor la bajeza de su esclava (Lc 1,48), dijo ella de sí. A Eva la grandeza la derribó. María, por ser chiquita, nos remedió, fue ella ensalzada. ${ }^{111}$

En el sermón de la Infraoctava del Corpus, viendo en el convite del rey Asuero una prefiguración de la eucaristía, proyecta el citado paralelismo en sus dos esposas: la primera, Vasti, "reina de desobediencia", figura a Eva; mientras la segunda, Ester, a María, compendio de virtudes en la que consiste su auténtica hermosura, sobre todo por lo que respecta a la obediencia de la fe:

En cuyo lugar [el de la reina Vasti] ordenó Dios que se buscase otra que no debiese nada en hermosura ni en natural a la primera reina, que le hiciese ventaja en virtudes; y fue hallada la bajita Ester, que es la sacratísimaVirgen María, nuestra Señora, hermosísima más que nuestra primera madre [Eva] y dotada de todas virtudes, limpísima, mansa, humilde, bien criada, honestísima, amorosa, en cuya boca nunca hubo palabra de desobediencia, sino que tengo para mí que dijo, mientras vivió en este mundo, infinitas veces las palabras que dijo al ángel: Ecce ancilla Domini; fiat mihi secundum verbum tuum. He aquí la esclava del Señor; sea hecho en mí según su voluntad (Lc 1,38). Palabra es ésta que la habían de decir siempre los cristianos y que nunca se había de quitar de su boca, y que la dicen los buenos y siervos de Dios en prosperidad y adversidad. ${ }^{112}$

111 Sermón 62, Obras completas, vol. III, 840.

112 Sermón 41, Obras completas, vol. III, 546. 
Además de animar a la imitación de María en la entrega total a Dios, interpreta su fiat no solo en el momento de la anunciación, sino como una constante a lo largo de su vida, concepto que infiere la perennidad de su fe, ${ }^{113}$ tal y como siglos después propuso Juan Pablo II. En la encíclica Redemptoris Mater, por ejemplo, el argumento en el que infiere a María al pie de la cruz recordando la profecía de gloria que recibió en la anunciación, ${ }^{114}$ parece hallar eco en el sermón de la Soledad ${ }^{115}$ en el que el maestro Ávila, relatando el momento en el que la Madre recibe el cuerpo inerte del Hijo, se vuelve a ella para reconfortarla, diciéndole:

Señora, aquí se cumple el Ecce ancilla (Lc 1,38) del día de la anunciación; que San Agustín dice que el mismo día que encarnó, ese día murió. Cotejad, Señora, día con día y templad la alegría de uno con la tristeza del otro. Acordaos, Señora, de la alegría que sintió vuestra ánima cuando el ángel os dijo que habíades de parir al Hijo de Dios, que venía a remediar el mundo perdido, que habíades de ser Madre de Dios, quedando virgen, para que no desmaye vuestro corazón con lo que agora tenéis delante de vuestros benditos ojos. Acordaos, Señora, de la alegría de aquel día, para que no desfallezcáis en los trabajos de éste. Aquí viene, Señora, Ecce ancilla, aquí viene el conformaros con la voluntad de Dios; alzad, Señora, los ojos al Eterno Padre y conformaros con su voluntad, para sufrir estas angustias con paciencia. Como allí os conformastes con la misma para aceptar lo que el ángel de su parte os decía. ${ }^{116}$

Ahondando en la renovación amarga de aquel fiat, pone en labios de María:

Padre de misericordia [...], veis aquí vuestra esclava, cúmplase en mí vuestra voluntad. Este Hijo me distes; con gran alegría le recibí. Veisle, ahí os lo torno; vos me lo distes, vos me lo quitaste, cúmplase vuestra santísima voluntad; esclava soy para todo lo que vuestra majestad quisiere hacer de mí. El

113 El Maestro Ávila ofrece numerosas alusiones a la fe de María en sus sermones, la fe vivida por ella misma y su ejemplaridad para la Iglesia. Cf. Juan EsquerDA BIFET, "María la creyente figura de la Iglesia creyente, en san Juan de Ávila", Estudios Marianos 80 (2014) 187-210.

114 Cf. Juan Pablo II, Carta encíclica Redemptoris Mater, 25-03-1987, 18.

115 Interpreta el dolor de María como expresión de su comunión con Cristo, a la vez que de las virtudes con las que afrontó su sufrimiento. Cf. Juan EsQuerda BIFET, "La Virgen Dolorosa, Madre de la Esperanza, en san Juan de Ávila", Estudios Marianos 81 (2015) 113-130.

116 Sermón 67, Obras completas, vol. III, 908. 
día de mi alegría os canté: Engrandezca mi ánima al Señor y gócese mi espíritu con Dios mi salud (Lc 1, 46-47); el día de mi tristeza y dolores suplícoos le recibáis en agradable sacrificio por los pecados de los hombres. ${ }^{117}$

A tenor de estas últimas palabras, se puede decir que el predicador entiende que la Madre no es ajena al sentido sacrificial de la muerte del Hijo, sino que, acorde con la doctrina de la compassio Mariae, la muestra copartícipe. De ahí que no apele a su dolor simplemente para conmocionar al oyente, sino, más bien, para animarle a la conversión, haciéndole cobrar conciencia de la gravedad del pecado por el que murió Jesús y sufrió su Madre. Por eso, justo antes del descendimiento, se dirige al oyente, diciéndole:

Pues luego por amor de ti atribula el Eterno Padre hoy a la Virgen, para que tú saques consuelo y provecho; por tu amor atormentan hoy a la Madre y al Hijo; sábelo por amor suyo conocer y agradecer; sábete aprovechar. No hayan agora padecido la Madre y el Hijo tan grandes trabajos y tormentos en balde; en balde sería si no hobiese quien se aprovechase del fruto de ellos. ${ }^{118}$

Y haciéndoles imaginar vivamente a la Madre afligida con el cuerpo del Hijo entre los brazos, pone en sus labios las siguientes palabras que habían de desgarrar los corazones de los oyentes:

¡Oh pecadores, cuán caro me costáis! ¡Cómo por amor de vosotros ha pasado mi corazón trance tan amargo como ha sido este, ver a mi Hijo padecer tan cruel muerte y pasión! Lo que vosotros hicistes, Él lo ha pagado, y mi ánima lo ha sentido: por bien empleado vaya, aunque ha pasado tantos trabajos, porque vosotros recibáis el fructo de ello y alcancéis perdón de Dios. ${ }^{119}$

No obstante, para no dejar el menor atisbo de una imagen severa de María, se vuelve a ella inmediatamente para decirle:"¡¡O Señora!, bendita seáis vos, que aún tenéis el sonido de las palabras de vuestro Hijo: ¡Perdonarlos! (cf. Lc 23,34)”. ${ }^{120}$ Perdón concedido por el Hijo que la Madre imita:

\footnotetext{
117 Sermón 67, Obras completas, vol. III, 909.

118 Sermón 67, Obras completas, vol. III, 901.

119 Sermón 67, Obras completas, vol. III, 909.

120 Sermón 67, Obras completas, vol. III, 909.
} 
Yo los perdono, Señor; y por la parte que me cabe de los trabajos que os he visto padecer por amor de ellos, perdonaldos, Señor; haceldes bien; consolaldos en sus tribulaciones; socorreldos en sus necesidades; ayudaldos en sus trabajos; oíldos, Señor, cuando os llamaren; alegraldos; haceldes bien por mí, Señor. ${ }^{121}$

Y habiendo conducido a la contrición, el predicador exhorta a imitar a María no solo en la concesión del perdón, sino para colmo, además, a tomar la iniciativa en ello:

Ecce ancilla. Aquí se cumplió bien el conformarse con la voluntad de Dios. ¡Oh dechado de madres! Perdonad; no esperéis que os vengan a rogar. ¿No veis a María, Madre bendita, que de buena gana perdonó la muerte de su bendito Hijo, y estando aún corriendo sangre, fresco, recién muerto; y no espera que le vengan a rogar, antes ella ruega por los que le habían dado muerte, y por los que habían sido causa de ella? ${ }^{122}$

Es en el Calvario donde la asociación de la Madre con el Hijo llega al punto de compartir el sufrimiento por la redención de los hombres. El predicador, removiendo las conciencias, usa al respecto una metáfora de hondo calado sacrificial, Cristo como Cordero y María como Oveja: ${ }^{123}$

Cosa es recia, por cierto, que ande la espada de Dios hiriendo a Jesucristo y a la sacratísima Virgen, su Madre, y que no nos pongamos nosotros delante: ¡¡Señor!, ¿qué es esto? ¿Qué os han hecho esta Oveja y su Cordero inocentísimo, los limpios, los sin pecado, los justos? ¿Qué culpa tienen? Estas ovejas inocentísimas son, que no hicieron por qué, que nosotros somos los traidores que os ofendimos, nosotros somos los que pecamos; vuélvase vuestra ira contra nosotros". ${ }^{124}$

Interpretando en clave soteriológica lo que sucede en el Calvario, Juan de Ávila se ayuda de su prefiguración preferida a la hora de

121 Sermón 67, Obras completas, vol. III, 909.

122 Sermón 67, Obras completas, vol. III, 909.

123 Dicha metáfora hubo de complacerle, dado que uno de sus biógrafos interpreta a la luz de esta su devoción mariana:"como este padre era tan amigo del Cordero, así también lo era de la Oveja que lo parió y crió. Quiero decir, que como era tan amigo del Hijo, así lo era de la Madre. Ca es tan grande la unión y liga que hay entre Hijo y Madre, que quien ama mucho al uno ha de amar mucho al otro" (Granada, "Vida del Padre Maestro", 96).

124 Sermón 67, Obras completas, vol. III, 896. 
expresar la asociación de María a la obra redentora de Cristo, la del paralelismo antitético con Eva y el principio de recirculación; de manera que a la pregunta que el predicador lanza sobre por qué "esta oveja inocente"sufrió tanto dolor, responde Dios, diciendo:"por donde se perdió el mundo, por ahí se ha de tornar a cobrar. Hombre y mujer le han de tornar a cobrar. ¡Negra manzana y negros deleites, qué caros habéis costado al Hijo, y por eso a la Madre! Adán y Eva perdieron el mundo; Cristo y María lo han cobrado". ${ }^{125} \mathrm{La}$ "manzana negra" evoca la desobediencia de la primera Eva por la que se introdujo el pecado, sobreentendiéndose que el árbol de la cruz es la antítesis del otro de donde esta cogió la fruta: ${ }^{126}$

Alzó los ojos la primera madre Eva para ver el árbol de que Dios le había mandado que no comiese. Alzó los ojos la Virgen María a Jesucristo en la cruz. Más lastimó a la Virgen ver cuál estaba Jesucristo que agradó y deleitó ver a la primera doncella el árbol que le estaba vedado que no comiese. ${ }^{127}$

La comunión de la Madre con el Hijo es tal para el maestro Ávila que además del parentesco físico existente naturalmente entre ambos, advierte el espiritual, siendo este el más perfecto que se haya dado, y esto, parenéticamente, para animar a imitar las virtudes de la Virgen:

Y como, entre todos los cercanos a Él, ninguno haya tanto como su Madre, nadie como ella nos enseña las virtudes con que le hemos de agradar. Y quien bien mirare la vida de la Virgen, verá en ella una grandísima semejanza de la de su Hijo nuestro Señor; porque convenía que así como ningún parentesco hay tan cercano como entre madre e hijo, y se suelen parecer mucho en el rostro, y particularmente fue esto entre nuestra Señora y su Hijo, y así convino que en lo espiritual ningún parentesco ni semejanza hubiese tan grande entre los hombres y Cristo, ni entre los ángeles y Cristo, como entre Él y su Madre. ${ }^{128}$

En razón de esto se ha de decir que la apreciación de la omnicontinencia de la Virgen en cuanto a las virtudes no es solo para

125 Sermón 67, Obras completas, vol. III, 901.

1261 árbol del Paraíso aparece en otros sermones como figura de la cruz y en el contexto del principio de recirculación. Cf. José L. Moreno Martínez, “Figuras bíblicas de la cruz en San Juan de Ávila", en AA.Vv., El Maestro Ávila, 655-656.

127 Sermón 67, Obras completas, vol. III, 903.

128 Sermón 66, Obras completas, vol. III, 887. 
engrandecerla, sino también y sobre todo para interpelar a los oyentes al camino de la santidad. ${ }^{129}$ Igualmente, es interesante que vaya más allá del parentesco natural que une a Madre e Hijo para fijarse en el espiritual, condición que propicia el culto de imitación.

Los sermones asuncionistas están repletos de alusiones a esta unión indisoluble, constituyendo la ausencia del Hijo para la Madre un verdadero martirio de amor, más doloroso aún que el que padeció al pie de la cruz:"Señora, vos, la que más allí padecistes, os tornan a dar a beber el cáliz de amargura de la ausencia de vuestro benditísimo Hijo, más penoso para vos que la muerte que os pudieran dar los sayones crueles". ${ }^{130}$ De la pregunta que a continuación hace el predicador a Cristo sobre el dolor de la Madre por el dilatado reencuentro se deduce que la asunción no solo se fundamenta en la maternidad divina, sino también en la cooperación a la obra redentora del Hijo:

¿Quién dijera que pidiérades más trabajos a esta Virgen bendita que los que pasó al pie de la cruz viéndoos morir en ella con graves dolores? Vos, Señor, sois el sol y ella la luna; y pues que ella se eclipsó cuando vos os eclipsasteis, ¿por qué cuando vais lleno de lumbre y de gloria, no participa ella también de lo que vos en tanta abundancia? La sombra sigue al cuerpo, y la Virgen a vos, y de vos está colgada como fidelísima sierva. ¿Por qué pues en el tiempo de vuestra tribulación ella os acompañó y siguió-, por qué os vais al cielo con mucha prosperidad y la dejáis a ella en la tierra? ${ }^{131}$

La relación de María con Cristo, además de ser materno-filial, lo es, en sentido espiritual, esponsal, en cuanto que la Madre se halla asociada a la obra redentora del Hijo, a la vez que revela el amor que ambos se profesan:

En la dignidad era Madre y Esposa, y por el perfectísimo amor que entre ellos había, Él tenía a ella por cosa muy suya; y las mercedes que le hacía, como en tal cosa las hacía; y ella tenía a Él tan abrazado con tan grande amor de su corazón, que lo amaba cien mil veces más que a sí misma. ${ }^{132}$

129 Cf. Molina Prieto, "Colaboración de María", 223:"el Maestro Ávila [expone] sus privilegios dogmáticos, pero hace fuerte hincapié en aplicar su ejemplaridad omnicomprensiva. Así, María es Madre de Dios, Virgen, Inmaculada y Asunta, pero es también modelo de vida cristiana, paradigma perfecto de virtudes evangélicas: está muy cercana de nosotros de tal modo que podemos y debemos imitarla".

130 Sermón 70, Obras completas, vol. III, 950.

131 Sermón 70, Obras completas, vol. III, 949.

132 Sermón 69, Obras completas, vol. III, 937. 
En uno de estos sermones concreta la raíz del parentesco espiritual de la Madre con el Hijo: la caridad; ofreciéndonos una reflexión realmente impresionante en la que, transparentando su honda espiritualidad contemplativa, se imagina a María en la fragua del amor divino. Dirigiéndose, pues, a Cristo y en nombre de los que oían el sermón, le dice:

Te bendecimos porque nos diste a tu Madre por madre; que como es la cosa más conjunta contigo en el parentesco de la carne, así lo es en el fuego de la caridad.Y como un hierro echado en el fuego está todo lleno de él, que parece el mismo fuego, así esta Virgen bendita, echada en el horno del divino amor, sale toda tan llena de él y tan semejable a él, que es tan verdadera madre del pueblo cristiano, que en comparación de ella las madres no merecen nombre de madres. ${ }^{133}$

Ante tal derroche de caridad, el predicador invita a seguir los pasos de tan buena Madre y, consecuentemente, a comportarse así como verdaderos hijos suyos, por lo que le suplica a la Virgen "nos alcance gracia de tu benditísimo Hijo para serte siquiera en algo leales e imitadores de tu mucha caridad y lealtad con que tú nos eres madre, y muy piadosa". ${ }^{134}$

\section{LA MATERNIDAD ESPIRITUAL}

En cuanto que Cristo, por su encarnación, es nuestro hermano, María es nuestra madre: "mira cuánto la engrandeció [Cristo] en hacerla madre suya. Más hijos tiene laVirgen María, con no parir más de uno, que otra que hobiese parido muchos, porque todos los que somos hermanos de Jesucristo, que somos los cristianos, todos somos hijos de la Virgen". ${ }^{135}$ En otro lugar, comparándola con Raquel, distingue ambas maternidades, la divina y la espiritual:

Raquel dos hijos tuvo; la Virgen benditísima dos hijos tiene, uno natural y otro adoptivo. El Hijo natural ya está en el cielo, ya está reinando, en cobro está, no tiene que pedir para Él. Resta que a los que somos hijos adoptivos nos alcancéis gracia para bien hablar, y para bien obrar, y para bien acabar. ${ }^{136}$

133 Sermón 69, Obras completas, vol. III, 945.

134 Sermón 70, Obras completas, vol. III, 962.

135 Sermón 62, Obras completas, vol. III, 840.

136 Sermón 28, Obras completas, vol. III, 334-335. 
De estas últimas palabras con las que introduce el sermón se deduce una de las consecuencias de la maternidad espiritual de María, su intercesión celeste. A este respecto, cabe destacar una de las reflexiones en la que engarza el fin soteriológico de la maternidad divina con la espiritual, dando a entender, además, el cariz materno de su mediación: “¿cómo menospreciará al pecador, pues fuimos causa de su dignidad; que para salvar los pecadores la tomó Dios por Madre, y somos hermanos de su bendicto Hijo, y ella Madre nuestra, y ansí la cantamos: Monstra te esse Matrem?". ${ }^{137}$

En la época del maestro Ávila ya era común entre los teólogos la interpretación de las palabras del Crucificado a su Madre como fundamento de la maternidad espiritual, de lo que se deduce la función representativa del discípulo amado que la acoge. ${ }^{138}$ Animando, entonces, a recurrir a la mediación de la Virgen, considera la maternidad espiritual instituida por Cristo en el Calvario como su principio, siendo esta un don de Dios:

El Hijo nos dio gran don en darnos a su bendita Madre por abogada nuestra. Sé que cuando Él dijo a San Juan al pie de la cruz: Ve ahí a tu madre (Jn 19, 27), en nombre de todos dijo; allí entramos todos los cristianos. Danos Dios a su Madre por madre; agradezcámoselo, y agradézcanselo los ángeles. Si esto hiciéredes, si pusiéredes al Hijo delante del Padre y a la Madre delante del Hijo, gran señal tenéis de salvación. ${ }^{139}$

En otro lugar sostiene que la intercesión de María como abogada nuestra ante su Hijo se debe a la encomienda materna que este le hizo desde la cruz:

No está olvidada de que, al pie de la cruz, le encomendó su Hijo a los cristianos en persona de San Juan diciendo: Ecce filius tuus (Jn 19, 26). No hace su oficio flojamente; no tiene descuido en lo que Dios le encomendó. Con humildad le ruega, con perseverancia le suplica. ${ }^{140}$

Destello de su celo apostólico es la comprensión alegórica de la maternidad espiritual de María a modo de pastorado, por lo que la

137 Sermón 65 [2], Obras completas, vol. III, 879. “Demuestra que eres madre”. Brev. Rom., Comm. Fest. B.M.V., ad Ves., hymn. "Ave maris stella".

138 Cf. Gabriel M. Roschins, La Madre de Dios según la fe y la teología, vol. I, Madrid, Apostolado de la Prensa, 1955, 441-442, páginas en las que cita a nuestro autor.

139 Sermón 63, Obras completas, vol. III, 854.

140 Sermón 68, Obras completas, vol. III, 922. 
llama Pastora, precediendo al que siglos después propagara y fundamentara dicha advocación mariana, el misionero capuchino fray Isidoro de Sevilla (1662-1750): ${ }^{141}$

Muy bien supo el Señor lo que hizo en dejar tal Madre en la tierra, y muy bien se cumplió lo que estaba escrito de la buena mujer, que confió en ella el corazón de su marido (Prov 31,11). Porque lo que su esposo y hijo Jesucristo había ganado en el monte Calvario derramando su sangre, ella lo guardaba y cuidaba y procuraba de acrecentar como hacienda de sus entrañas, por cuyo bien tales y tantas prendas tenía metidas. ¡Dichosas ovejas que tal pastora tenían y tal pasto recibían por medio de ella! Pastora, no jornalera que buscase su propio interese, pues que amaba tanto a las ovejas (cf. Jn 10,12), que, después de haber dado por la vida de ellas la vida de su santísimo Hijo, diera de muy buena gana su vida propia, si necesidad de ella tuvieran. ${ }^{142}$

A estas palabras le sigue uno de los comentarios en los que propone a María como ejemplo para los sacerdotes en su ministerio pastoral: ${ }^{143}$

¡Oh qué ejemplo para los que tienen cargo de ánimas! Del cual pueden aprender la saludable ciencia del regimiento de ánimas, la paciencia para sufrir los trabajos que en apacentarlas se ofrecen.Y no sólo será su maestra que los enseñe, mas, si fuere con devoción de ellos llamada, les alcanzará fuerzas y lumbre para hacer bien el oficio. ${ }^{144}$

En ocasión de la celebración de Pentecostés, nos ofrece una reflexión preciosa en la que explica la maternidad espiritual de María con relación al Espíritu Santo, ${ }^{145}$ el mismo que obró en ella el misterio de la encarnación y que, habiendo inundado sus entrañas y su corazón para tal efecto, Él que es amor, la capacitó para amarnos con semejante desmedida:

141 Hace unos años tratábamos la doctrina avilista entre los precedentes del citado capuchino. Cf. Álvaro Román Villalón, La Divina Pastora en los escritos de fray Isidoro de Sevilla (1662-1750), Sevilla, Gesto Sevilla Comunicación, 2012, 480-489.

142 Sermón 70, Obras completas, vol. III, 961.

143 Cf. Juan Esquerda BifEt, "Espiritualidad sacerdotal mariana en Juan de Ávila", Estudios Marianos 35 (1970) 85-114.

144 Sermón 70, Obras completas, vol. III, 961.

145 Cf. Andrés Molina Prieto, "Valores pneumatológicos de la mariología avilista", Estudios Marianos 41 (1972) 117-149. 
Puesto caso que la Virgen santa María nuestra Señora a sólo Jesucristo nuestro Redemptor tuvo, y fue su Hijo natural; pero porque fue allí derramado el Espíritu Santo abundantemente en su corazón y entrañas, ámanos en gran manera, ámanos entrañablemente. No hay comparación de esposo a esposa, ni de madre a hijo, ni de hijo a padre; más fuerte es el amor espiritual que como a hijos adoptivos nos tiene. — ¿De dónde es esto? - El mismo Espíritu Santo es ternura, es amor: Deus charitas est (1 Jn 4,16). ${ }^{146}$

\section{ASUNTA EN CUERPO Y ALMA}

Antes de proseguir con la mediación celeste de María que se ha ido perfilando en el apartado sobre la maternidad espiritual, trataremos brevemente la asunción de laVirgen, tema del que se conservan cuatro sermones ${ }^{147}$ que comparten la idea central de "que María, asociada a todos los misterios de Cristo en su vida terrena, fue glorificada en cuerpo y alma". ${ }^{148}$

Para el maestro Ávila los argumentos teológicos que explican la asunción de la Virgen corresponden a tres privilegios: la inmaculada concepción, la virginidad perpetua y la maternidad divina, ${ }^{149}$ ocupando especial protagonismo este último, como cuando refiere la resurrección de la Madre por parte del Hijo:

Pues representada por la pureza de holanda y ganada con trabajos como la blancura de holanda, ${ }^{150}$ viste hoy el Señor benignísimo al ánima de su sacratísima Madre, y también hoy, o al tercero día, le resucita su santísimo cuerpo, y, vestido de gloria, lo junta con el ánima, que tiene más gloria; y toda su Madre entera, en cuerpo y en alma, la manda poner sobre su carro el sigundo, dándole el sigundo lugar de la gloria y del universal señorío, después de él. Porque el primero y principal carro, en que nadie sino Jesucristo nuestro Señor, en cuanto hombre, anda, es que por la unión hipostática el hombre es verdadero Dios, no por gracia, sino por naturaleza; tras la cual dignidad, a la cual ninguno llegó sino Él, es la dignidad de la Virgen, por ser madre, no de hombre sólo, mas del verdadero Dios humanado. Esta

146 Sermón 32, Obras completas, vol. III, 388.

147 Cf. Andrés Molina Prieto, "Los tres sermones asuncionistas de san Juan de Ávila", en Ignazio M. Calabuig (coord.), Virgo Liber Verbi. Miscellanea di studi in onore di P. Giuseppe M. Besutti, O.S.M., Roma, Marianum, 1991, 281-309.

148 EsQUERDA, “La doctrina mariológica”, 107.

149 Cf. Molina PRIETO, "Los tres sermones asuncionistas”, 303.

150 Vestiduras que evocan la gloria del Señor transfigurado $($ Lc 9,29) y la de los bienaventurados del Apocalipsis $(3,4)$. 
dignidad le fue dada cuando concibió al Hijo de Dios, y hoy es puesta sobre el sigundo carro de la gloria, conviniente a tal dignidad. ${ }^{151}$

De aquí se deduce que la asunción de María pasa por la experiencia de la muerte y la resurrección que, para mayor semejanza con Cristo, acontece al tercer día. No obstante, la razón de la muerte de la Virgen para el maestro Ávila no tiene nada que ver con el pecado, pues esta no lo conoció, aconteciendo más bien para que se configurara mejor con el Hijo que venció a la muerte resucitando. En otro momento, presenta la curiosa metáfora de la silla rota para expresar la muerte de la Virgen, o sea, la separación del alma y el cuerpo, mientras que la resurrección es significada por su reparación por parte de Cristo, dando a entender la maternidad divina como argumento de conveniencia de dicho misterio:

Es, por cierto, cosa muy justa que, pues en cuerpo y en ánima fue la Virgen bendicta silla de Dios, y por muy particular manera, que ya que se partió esta silla en dos partes en el día de su muerte, que luego o al tercer día, torne Dios a juntar su silla y santísima arca, para que vean todos los que en el cielo estuvieren aquella santísima carne, de la cual el Verbo divino tomó carne humana, y que esté tan resplandeciente, que baste a alumbrar todo el cielo y henchir de nueva alegría a todos los que allá están. Y así es de creer que lo pidieron los ángeles, y que Dios lo concedió, y que toda la Virgen entera está reinando en el cielo sobre todas las cosas que desea su ánima; y una de ellas era, sigún hemos dicho, tener consigo su benditísimo cuerpo, descansando para siempre bienaventurada. ${ }^{152}$

De los momentos previos a la asunción de María y de la causa de su muerte, el amor, se infiere la" dimensión eclesial y contemplativa"153 de este misterio, siendo uno de los ejemplos más sobresalientes de la impronta mística de la espiritualidad avilista, proyectada en la etapa final de la vida terrena de la Virgen. La primera dimensión, la eclesial, pone de relieve la presencia de María en la primitiva comunidad cristiana desde la ascensión del Señor a su nueva forma de estar en la Iglesia tras su asunción, según el estado glorioso adquirido por la resurrección. Una de las razones por la que Cristo quiso que su Madre prolongara su estancia en la tierra tras su ascensión fue para

151 Sermón 71, Obras completas, vol. III, 985.

152 Sermón 69, Obras completas, vol. III, 943-944.

153 Cf. Esquerda, “La doctrina mariológica”, 107. 
que sirviera de provecho a los cristianos de entonces, dándoles, por ejemplo, consejo, de manera que estos la buscaban"para ser enseñados de los caminos de los mandamientos de Dios y las sendas [cf. Is 2,3]; que para lo uno y lo otro y para todas cuantas necesidades traían les daba suficiente consejo y remedio la prudentísima y santísima Madre" ${ }^{154}$ En masa iban a su encuentro atraídos por el perfume de sus virtudes y por su caridad materna:

Era tanto el concurso de los cristianos a ver esta arca preciosa de Dios, que lo trajo encerrada en sí mesma, que los caminos para su casa iban llenos de gente, y no sólo los de la ciudad de Jerusalén, mas fuera de ella, corriendo los unos y los otros movidos por el Espíritu Santo y provocados de fuera con el dulcísimo olor de sus ungüentos (Cant 1,3), que era la odorífera fama de sus virtudes, el grande amor con que recibía a los que iban a ella, su grande misericordia, que a ninguno desechaba, y aquella gran maravilla y milagro y altísima dignidad de que era verdadera Madre de Dios. ${ }^{155}$

Como decíamos, los sermones asuncionistas son los que mejor expresan la influencia de su espiritualidad ascética en la imagen que se hace de María, ${ }^{156}$ de manera que el deseo ardentísimo de esta por reencontrarse con el Hijo es interpretado por la vía de la perfección que se basa en el amor, siendo numerosas las referencias a esta virtud teologal que, según el predicador, lleva a laVirgen a vivir un auténtico martirio, siéndole el amor como una prisión o una enfermedad, una herida que comparte con el Hijo:

Herida y presa [cf. Os 11,4] estaba la Virgen del amor divinal, más que ninguna criatura; y herido y preso tenía a su Señor y su Dios, más que ninguna criatura. Ni el Señor ni ella querían resistir a las heridas y prisiones de amor, antes se daban de muy buena gana tan sujetos al señorío del que obraba en ellos cuanto quería. Salvo que en Dios no podía obrar pena, y toda caía sobre la Virgen bendita; porque Él es del todo impasible, y ella muy aparejada a padecer martirio de amor. ${ }^{157}$

154 Sermón 70, Obras completas, vol. III, 960.

155 Sermón 70, Obras completas, vol. III, 960.

156 Cf. Juan Esquerda BifET, "La oración contemplativa en relación a la devoción mariana según el Maestro Juan de Ávila", Anthologica Annua 24-25 (1977-1978) 499-550; Ramón Jimeno, La mariología estática en el Maestro Ávila, Tesis Doctoral, Granada, Facultad de Teología de La Cartuja de Granada, 1955.

157 Sermón 70, Obras completas, vol. III, 954. 
El colofón de la glorificación de María con su coronación como Reina de todo el universo lo describe análogamente a la exaltación de Cristo según el himno de los Filipenses (2,9-10). De este modo, citando la antífona del Oficio divino y evocando el Cantar de los Cantares, dice:

¡Oh benditísima y prudentísima Virgen!, ¿dónde vais hoy, hija de Sión, toda hermosa y suave, reclinada en los brazos del Amantísimo de tu corazón? ¿Dónde vas sino a recibir corona de gloria sobre todo lo criado y que se ha de criar, y que toda rudilla del cielo y de la tierra y debajo de ella se te incline, por voluntad o por fuerza, y te sea dado todo nombre sobre todo nombre y que sólo tu Hijo te exceda? ${ }^{158}$

La realeza de María se traduce en el ejercicio de su mediación, distribuyendo, cual limosnera, las gracias de Dios a los hombres, expresión de su cooperación a la redención subjetiva:

Oigamos cómo el bendicto Señor, subiendo hoy al cielo a su sacratísima Madre, le dice con gran dulcedumbre: "Madre mía, tú serás eternalmente sobre toda mi casa, y todo el pueblo de mi celestial corte y de la tierra y debajo de ella, será obediente a lo que tu boca mandare; solamente te precederé en una silla del reino, porque yo soy Dios criador, y vos criatura y Madre mía". Tras las cuales palabras quitó el anillo de su mano y lo puso en la de ella, para que tenga poder y autoridad para refrendar todas las mercedes que Dios al mundo hiciere, y que la que no fuere por su mano refrendada ni viniere por medio de ella, no sea tenida por verdadera, ni que viene del cielo; y que es hecha universal limosnera de todas las gracias y limosnas que Dios a los hombres hiciere. ${ }^{159}$

En los sermones asuncionistas dirige constantemente la atención de los oyentes, animándolos a aspirar a los bienes de arriba y, por ende, a convertirse, siguiendo el ejemplo de la que sube al cielo no solo por sus prerrogativas, sino también como premio a su santidad de vida:

Fue tanto el conocimiento y amor que de Dios tuvo, tanta la estima con que le preció, que por alcanzarlo, y por alcanzar mucho de Él, no sólo no deseaba las cosas de la tierra, mas ni aun las tomara, aunque se las dieran; tiniendo por cierto que cuanto más dejaba por Dios, tanto más ternía de Él;

158 Sermón 71, Obras completas, vol. III, 983.

159 Sermón 71, Obras completas, vol. III, 984. 
y por eso tenía, muy mejor que San Pablo, todas las cosas por estiércol (cf. Flp $3,8)$, porque Dios fuese precioso en sus ojos y muy amado de su corazón. Y no tenga nadie por agravio que se llamen estiércol los bienes de este mundo, pues que él no fue criado para morada de hombres, sino de bestias, y el tal lugar establo se llama, y lo que en él hay estiércol es. ¡Oh gente abatida, ratera y de pequeño corazón, que andáis desvelados, aperreados y muertos por henchir vuestras arcas y senos de vilísimo estiércol, y que mañana o esotro día lo habéis de dejar, y no os enamora Dios ni los bienes eternos, que son mayores que vuestro corazón puede comprehender! ${ }^{160}$

\section{LA MEDIACIÓN CELESTE}

Raro es el sermón en el que no refiera la mediación celeste de la Virgen, especialmente en el exordio, tanto en favor de él mismo en calidad de predicador, como de los oyentes. En el sermón de la Visitación de la Virgen, por ejemplo, dice:

¿Cómo profetizaré yo si no oigo a esta gran cantora, que hoy cantó el suavísimo canto de la Magnificat? Visitadnos, Señora, con vuestra intercesión; hablad por nos a Dios, para que yo hable bien de vos, y este auditorio oiga. Y porque a todos hagáis mercedes, humillémonos todos a vos, diciendo: Ave, Maria. ${ }^{161}$

La experiencia de la intercesión celeste de la Virgen es tal para el maestro Ávila que parece anticiparse a uno de los conceptos mariológicos más originales de san Juan Pablo II, el de la mediación materna de María a modo de presencia, ${ }^{162}$ de manera que el beneficio que Isabel y el Bautista reciben de esta visita le lleva a decir que"por la habla, por el medio de la Virgen les vino este bien; y así parece cuán provechosa nos es su intercesión y el encomendarnos a ella y con cuánta razón la debemos suplicar nos visite". ${ }^{163}$ Para alcanzar tal experiencia, el predicador exhorta a la verdadera devoción que va pareja a guardar los mandamientos de Dios y de la Iglesia, de manera que, de no hacerlo,"olvidado tenemos a Dios y a su ley, y por eso

160 Sermón 71, Obras completas, vol. III, 976-977.

161 Sermón 66, Obras completas, vol. III, 887.

162 Cf. Álvaro Román VilLaLón, “La mediación materna de María en el magisterio de Juan Pablo II", Estudios Marianos 84 (2018) 181-187.

163 Sermón 66, Obras completas, vol. III, 892. 
no somos visitados de la Virgen, que ella ansí lo siente, pues lo dice: Quodcumque dixerit vobis, facite (Jn 2,5)". ${ }^{164}$

El recurso a su intercesión es para el maestro Ávila instintivo en los hombres, al igual que Dios suscitó en ella que intercediera por nosotros:

Pues así acá ha puesto Dios este instinto en todos los cristianos de llamar luego a la Virgen María. En tiniendo una necesidad, luego: " Oh Señora, defiéndeme, ruega por mí a Dios!". Y pues todos la llamamos en nuestros trabajos, señal es que ha puesto Dios en el corazón de ella que ruegue a su Majestad; luego pues es nuestra madre. ${ }^{165}$

La comprensión de la mediación mariana se ajusta a la de su tiempo, recurriendo a uno de sus grandes referentes, san Bernardo de Claraval (1090-1153), al cual cita en varias ocasiones para tomar algunas ideas al respecto, como cuando recomienda la mediación de María por temor a Cristo:"si tienes miedo de allegarte a Jesucristo, porque no sólo es hombre, hermano tuyo, sino omnipotentísimo Dios de majestad infinita, allégate a esta Virgen sagrada, mansa y piadosa, y que no tiene otra naturaleza más que la humana" ${ }^{166}$ Igualmente, la metáfora del cuello:

- ¿Quién es la cabeza?

-Cristo.

—¿Quién es el cuerpo?

-La Iglesia.

— ¿El cuello, quién?

- La que trataba con sus oraciones el cuerpo con la cabeza, medianera entre Dios y los hombres, más alta que nadie; y cerca de nosotros por misericordia; más alta que nadie, pero más baja que todos en sus ojos. ${ }^{167}$

Otra metáfora con la que suele explicar la mediación celeste de María es la del"muro", con la que subraya su poder intercesor ante el Hijo en favor del pecador. En un sermón de la Natividad de la Virgen, preguntándose sobre la identidad de la recién nacida a la luz de Cant 8,9, dice:" ¿quién es esta Niña? Es un fortísimo muro. ¡Oh bienaventurada Señora! ¡A cuántos has defendido, en los cuales quería Dios ejecutar su justicia! Poniéndote en medio, rogando por ellos, les has

\footnotetext{
164 Sermón 66, Obras completas, vol. III, 893. "Haced lo que Él os diga".

165 Sermón 62, Obras completas, vol. III, 841.

166 Sermón 60, Obras completas, vol. III, 809.

167 Sermón 63, Obras completas, vol. III, 852.
} 
alcanzado perdón de pecados" ${ }^{168}$ En otra ocasión, recordando la devoción de la Madre de Misericordia, alude al manto protector de la Virgen, reflexión de la que se desprende el cariz materno de su mediación. Además de concatenar la maternidad divina con la espiritual, repárese en que la mediación de María no es solo relativa al pecador, sino también a los justos, doble apreciación que reitera constantemente en sus sermones.

Afecto de Madre, corazón de defensora tiene esta Niña para todos los hombres; mirad si ha menester ser larga para ser madre de tantos hijos. Niña, ¿de dónde tenéis vos manto para cubrirnos a todos? ¿De dónde alas para abrigar a tantos pollitos? ¡Más ancha que la tierra! Caben en ella justos y pecadores; los pecadores son perdonados por los ruegos de ella, y los justos conservados en gracia; [cabe] quien no cabe en el cielo, más ancho que la tierra, y cielo y ángeles; que pues Dios entró en ella y cupo en ella, ¿no cabrás tú, pecador? Sancta et immaculata virginitas, quibus te laudibus efferam nescio, quia quem caeli capere non poterant, tuo gremio contulisti. El que no cabe en los cielos, en tus entrañas se encerró; ${ }^{169}$ bien cabrás, pecador, en las entrañas de la Virgen. ${ }^{170}$

La razón por la que María no cesa de interceder por justos y pecadores es su inextinguible caridad, de modo que aun y cuando goza de la gloria del cielo, no se desentiende de ellos. De este modo, el predicador pone en labios de María:

No he perdido la compasión de ellos ni el deseo de su salvación que tenía en el mundo, antes se me ha acrecentado, porque el Señor me ha acrecentado la caridad. Este cuidado terné hasta que el mundo se acabe, este oficio haré: ser fiel abogada de los negocios de ellos delante el trono de Dios; y cuando lo viere enojado con ellos, ponerme he delante, $y$, si menester fuere, hincaré mis rodillas, y echarme he a sus pies, y traerle he a la memoria los servicios que Él me dio gracia que yo le hiciese y Él recibió de muy buena gana, y haré todo aquello que una amorosísima madre hace con sus hijos, sin cansarme ni enfadarme de abogar por justos y por pecadores. ${ }^{171}$

168 Sermón 62, Obras completas, vol. III, 840.

169 "Santa e inmaculadaVirgen, no sé con qué alabanza loarte, porque al que los cielos no pueden contener, tú lo llevaste en tu seno". Brev. Rom., Comm. Fest. B.M.V., resp. 1 ad Mat.

170 Sermón 63, Obras completas, vol. III, 854.

171 Sermón 69, Obras completas, vol. III, 944. 
Una de las imágenes más sugestivas con la que pretendía remover la conciencia de los oyentes y animarlos a abandonar la vida de pecado es la figuración de la Virgen como enfermera del hospital de la misericordia de Dios: ${ }^{172}$

En vuestras manos, Señora, ponemos nuestras heridas para que las curéis, pues sois enfermera del hospital de la misericordia de Dios, donde los llagados se curan. Y aunque tenemos gran confusión y vergüenza de presentar delante de tanta limpieza la hediondez de nuestras abominables llagas, creemos que os dotó Dios de tanta misericordia, que vuestra limpieza y pureza no se desdeña ni alanza de sí a los pecadores llagados, mas que cuanto es mayor su necesidad, tanto más vuestra misericordia os mueve a su remedio, conformándoos con vuestro Hijo bendito, que no vino a llamar justos, sino a pecadores a penitencia (cf. Mt 9,13). ${ }^{173}$

La llamada a la responsabilidad a la que apelan sus sermones cuando refiere los novísimos ofrece una de las expresiones más vivas de su lenguaje parenético. La mención del Juicio Final, por ejemplo, le "sirve de aliciente para corregir conductas personales y sociales". ${ }^{174}$ En este sentido, se comprende la dura advertencia que hace en uno de los sermones de Adviento a propósito de la tensión escatológica que suscita la espera de la venida del Señor, ante la cual, ni siquiera valdrá la intercesión de la Virgen, a la que se ha de recurrir más bien en el presente con el fin de perseverar en lo que realmente conviene para la salvación futura.

¿Quién será tan esforzado, tan justificado, que, metiendo la mano en su pecho, no terná mucho que temer aquel día, y, lo que más terrible es, que será tan estrecho que no podrá valer hermano a hermano, ni santo a pecador, ni la abogada de los pecadores, la Virgen nuestra Señora, no podrá remediar a nadie? Tan derecha estará la vara del juez, tan determinado estará Dios de dar a cada uno según sus obras, que ni aprovechará su sangre, ni su pasión, ni su bendita Madre. Decid: ¿es razón que nos ponga esto en cuidado para que miremos lo que nos conviene antes que nuestra vida se

\footnotetext{
172 Cf. Juan Esquerda Bifet, "María, Madre de misericordia, en san Juan de Ávila", Estudios Marianos 83 (2017) 293-328.

173 Sermón 60, Obras completas, vol. III, 815.

174 ESQUERDA, Introducción a la doctrina, 246.
} 
acabe, antes que venga este día, antes que se nos acabe la luz? Alcemos los ojos a vos ahora, Señora, que es tiempo. Alcanzarnos la gracia. ${ }^{175}$

\section{CONCLUSIÓN}

La imagen que san Juan de Ávila presenta de María en sus sermones no deja indiferente a nadie. Expone sus misterios y su vida virtuosa con tal ardor y propósito apostólicos que acomoda su intelección con el fin de despertar los afectos de los oyentes en el camino de la perfección, es decir, de la conversión y la consecuente santidad de vida. Por eso, puede decirse que la argumentación de su doctrina es un claro exponente de lo que venimos a llamar una mariología parenética, en tanto que la transmisión del concepto teológico se amolda dinámica y coloquialmente para interpelar las conciencias de los asistentes a la predicación. La consecuencia cultual que de ello se deriva es el constante reclamo por parte del predicador de una devoción más auténtica, consistente, sobre todo, en la imitación de las virtudes por las que la Virgen misma se ejercitó de forma ejemplar, tal y como en uno de sus sermones advierte a sus oyentes: "quererla bien y no imitarla poco provecha". ${ }^{176}$

En razón, pues, de la orientación parenética de su discurso, la exposición de temas doctrinales tan admirables para el devoto como el de la inmaculada concepción no se reduce a la consideración sobre el privilegio mariano de la exención de la culpa original, de manera que así como María se ejercitó en una vida virtuosa, quien desee venerarla ha de esforzarse en imitarla, verdadero signo de amor hacia ella.

Del mismo modo, la contemplación de la maternidad divina que tanto sobrecoge ha de conducir a la más absoluta contrición, reparando en el gesto amoroso y gratuito de un Dios que se encarna y se hace depender de una madre que lo cuida. El hecho de que esta se desprenda del recién nacido para ponerlo en el pesebre, premonición de la ofrenda redentora del Cordero, reclama el agradecimiento y la conversión. Incluso la relación de María con la eucaristía, mediante la

Sermón 1 [1], Obras completas, vol. III, 5. Igualmente en Sermón 1 [2], Obras completas, vol III, 21 :"no nos aprovechará, como dicen los muchachos : ¡Ay, madre! No nos valdrá aquel día la Virgen, Madre [de] Dios, aunque la llamemos para nuestro socorro".

176 Sermón 64, Obras completas, vol. III, 854. 
encarnación delVerbo, le sirve para animar a los sacerdotes a tratar el sacramento al igual que ella trató a Jesús entre sus brazos.

Por la perspectiva parenética del sermón, la virginidad de María, entendida como voto, no solo es considerada por Ávila en sentido físico, sino también moral, exhortando a imitarla en la determinación de una vida casta.

La asociación incondicional de María a la obra redentora del Hijo también comporta el agradecimiento y el arrepentimiento del devoto, dado que por sus culpas la Madre sufrió junto al Redentor. Su dolor, dramáticamente figurado por el predicador, ha de conmocionar al oyente para animarle a una mayor conversión.

La maternidad espiritual de María es bálsamo consolador, destacando la metáfora por que la figura a modo de pastorado y la presenta como modelo de todo sacerdote en la caridad desinteresada con la que este ha de vivir su ministerio.

La asunción, entendida no solo como privilegio, sino también como premio a la santidad de vida, lleva al oyente a reconsiderar la suya, observando las virtudes por las que la Virgen fue elevada a la gloria, sobre todo la del amor, expresión de la mística del predicador que enciende en los devotos el deseo de profundizar en lo más recóndito del corazón de la Madre.

Finalmente, a la intercesión celeste de María apela constantemente para lograr una predicación acertada y eficaz, y obtener así la conversión de los oyentes. Eso sí, para el Maestro Ávila de nada sirve que se la invoque si no se imitan sus virtudes, la mejor expresión cultual que el devoto le pueda tributar. 
